\title{
1. THE GEOLOGIC AND TECTONIC EVOLUTION OF THE KERGUELEN PLATEAU: AN INTRODUCTION TO THE SCIENTIFIC RESULTS OF LEG 1201
}

\author{
Roland Schlich ${ }^{2}$ and Sherwood W. Wise, Jr. ${ }^{3}$
}

\begin{abstract}
The origin and subsequent geologic, tectonic, and paleoceanographic history of the Kerguelen Plateau in the remote southern Indian Ocean were the primary topics addressed by scientific drilling during Ocean Drilling Program (ODP) Leg 120 (February to April, 1988). Preliminary drilling results reported a year after the cruise in the ODP Initial Reports series disclosed no evidence for a continental origin of the plateau, suggesting instead that the feature originated from excessive oceanic volcanism. The Leg 120 Scientific Results volume presents the detailed shipboard and shore-based studies on which this and other conclusions concerning the origin and history of the Kerguelen Plateau are based.

The goal of this paper is to introduce the volume and to guide the reader to the individual papers and syntheses contained therein. To this end, it provides background information on the Kerguelen Plateau, summaries of the objectives for each of the five sites drilled, preliminary drilling results as given in the Initial Reports volume, highlights of the preliminary results, and, where sufficient material was recovered, brief developmental histories for each site. Where these preliminary results have been modified or expanded during subsequent shore-based studies, appropriate references are given to the more detailed single- and multi-authored chapters that follow in this volume.
\end{abstract}

\section{INTRODUCTION}

The 2,300-km-long Kerguelen Plateau in the remote Antarctic sector of the Indian Ocean is one of the largest submerged plateaus in the world (Fig. 1). The origin and subsequent geologic and tectonic history of this imposing feature have long been topics of debate and speculation, problems that the Ocean Drilling Program (ODP) Leg 120 scientists sought to investigate during their 69-day cruise out of Fremantle, Australia, from 21 February to 30 April 1988.

To this end, approximately $1081 \mathrm{~m}$ of core were recovered from 12 holes at 5 sites (747-751) occupied on the central and southern parts of the plateau during 28 operational days at sea (Fig. 1 and Table 1); 35 days were spent in transit. These holes complement the 6 sites previously drilled on the northern and southern parts of the Kerguelen Plateau and the 5 sites drilled on the adjacent Antarctic margin (Leg 119, Sites 736-746; see Fig. 1).

The scientists on Leg 120 planned to test conflicting hypotheses about the plateau's origin. Is it (1) a continental fragment, (2) the product of massive on- or off-axis mid-ocean ridge volcanism (possibly hotspot related), or (3) a thermally or tectonically uplifted (and possibly thickened) block of oceanic crust? Furthermore, we wanted to learn when the plateau formed and how this little-explored portion of the Southern Ocean evolved during its subsequent history.

As an introduction to the Scientific Results volume, this chapter provides background information on the Kerguelen Plateau followed by brief summaries of the objectives, drilling results, and highlights from each site. Where sufficient material was recovered, brief developmental histories are outlined for the sites. Most of this information, with appropriate

\footnotetext{
${ }^{1}$ Wise, S. W., Jr., Schlich, R., et al., 1992. Proc. ODP, Sci. Results, 120: College Station, TX (Ocean Drilling Program).

2 Institut de Physique du Globe, Université Louis Pasteur, Laboratoire de Géophysique Marine (CNRS UA 323), 5 rue René Descartes, 67084 Strasbourg Cedex, France.

${ }^{3}$ Department of Geology, Florida State University, Tallahassee, FL 32306, U.S.A.
}

updates, is taken from Schlich, Wise, et al. (1989). The basic drilling data are displayed and compared in various ways in Figures 2 through 5, and the frontispiece of this volume provides color illustrations of some of the more important core materials.

Within the site reports that follow, references are given to more detailed studies of the cores presented elsewhere in this volume by single and multiple authors.

Preliminary reports on the Leg 120 drilling results have been issued by the Leg 120 Scientific Drilling Party (1988), the Leg 120 Shipboard Scientific Party (1988), Schlich and ODP Leg 120 Scientific Party (1989), and Schlich, Wise, et al. (1989). Regional geophysical studies that incorporated data from the first three of these reports have been published by Coffin et al. (1990), Schaming and Rotstein (1990), and Rotstein et al. (1990). Reports of the companion Leg 119 drilling results have appeared in Barron, Larsen, et al. $(1989,1991)$. Also relevant are the results of ODP Leg 121 drilling on Broken Ridge (Sites 752-755; Peirce, Weissel, et al., 1989; Weissel, Peirce, Taylor, Alt, et al., 1991), a feature that was rifted from the eastern margin of the Kerguelen Plateau (Fig. 1). If reassembled, Broken Ridge and the Kerguelen Plateau together would constitute the world's largest oceanic plateau.

The Initial Reports and Science Results series are issued within less than $4 \mathrm{yr}$ of the cruise. Thus, the research is constrained by a production schedule for the volumes that entails a hierarchy of stringent deadlines. As the studies progress, preliminary age dates of the cores are continually updated and age models for various intervals are constructed and modified. These age models may be based on magnetostratigraphy, chemostratigraphy, one or more of the microfossil groups studied, or a combination of several or all of these approaches. Age dates and age models rendered by these various methods are not always in agreement; however, because of the tight publication schedules, it may not be possible to reconcile differences in age determinations before a volume must go to press. This is particularly true for high-latitude cruises such as Leg 120 for which the pertinent data bases are not extensive, many traditional index taxa are 
R. SCHLICH, S. W. WISE, JR.

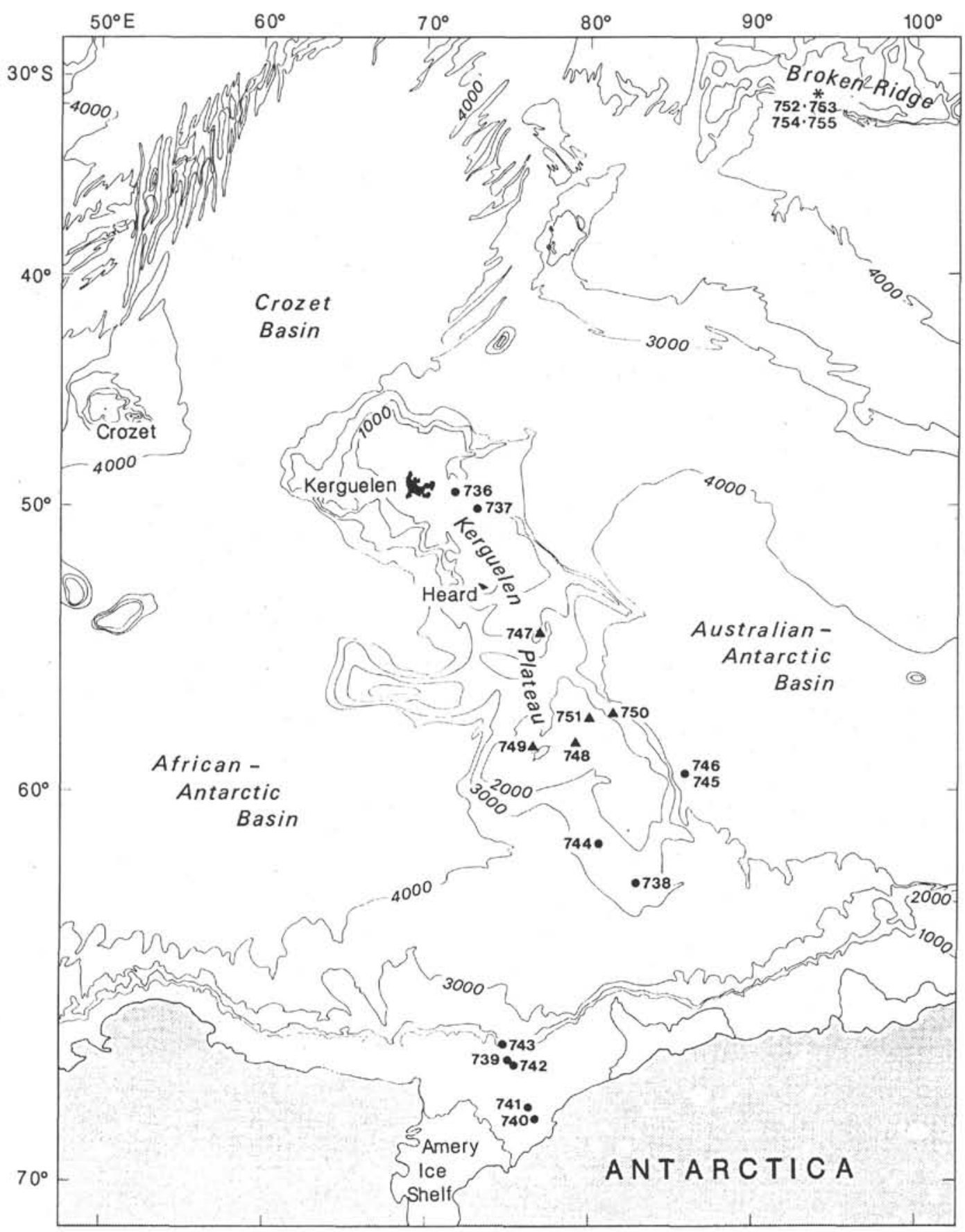

Figure 1. Location map of the Kerguelen Plateau showing the location of Leg 120 sites (triangles), previously drilled Leg 119 sites (dots), and subsequently drilled Leg 121 sites on Broken Ridge (*). Bathymetric contour interval is $1000 \mathrm{~m}$ (Hayes and Vogel, 1981; Fisher et al., 1982; Schlich et al., 1987).

rare or absent, and biostratigraphies for the region are still being developed.

The production process is such that it is not practical, under the circumstances, to impose on a volume of this nature "standard" biostratigraphies or age models to be used uniformly throughout the volume. Such an attempt would merely delay the publication beyond reasonable limits, and we make no such attempt here. Instead, we have encouraged the authors to develop biostratigraphies and age models as appropriate within the purview of their data and expertise, leaving discrepancies, if necessary, to be discussed in the synthesis chapters on biostratigraphy and resolved, if possible, during the course of future research. Integrated regional chronologies and biostratigraphies probably can best be achieved during future workshops that synthesize the results of several legs within an ocean basin. For these reasons, one may find discrepancies among the age determinations and age models presented in the chapters of this volume as well as in the Leg 120 Initial Reports volume (Schlich, Wise, et al., 1989) already published. We only asked the authors to identify clearly in their individual chapters the basis of age assignments for the cores they used. 
Table 1. Summary of Leg 120 sites.

\begin{tabular}{lccccrrrr}
\hline Hole & $\begin{array}{c}\text { Latitude } \\
\left({ }^{\circ} \mathrm{S}\right)\end{array}$ & $\begin{array}{c}\text { Longitude } \\
\left({ }^{\circ} \mathrm{E}\right)\end{array}$ & $\begin{array}{c}\text { Water } \\
\text { depth } \\
(\mathrm{m})^{\mathrm{a}}\end{array}$ & $\begin{array}{c}\text { No. } \\
\text { of } \\
\text { cores }\end{array}$ & $\begin{array}{c}\text { Cored } \\
(\mathrm{m})\end{array}$ & $\begin{array}{c}\text { Recovery } \\
(\mathrm{m})\end{array}$ & $\begin{array}{c}\text { Recovery } \\
(\%)\end{array}$ & $\begin{array}{c}\text { Penetration } \\
(\mathrm{m})\end{array}$ \\
\hline $747 \mathrm{~A}$ & $54^{\circ} 48.68^{\prime}$ & $76^{\circ} 47.64^{\prime}$ & 1695.0 & 27 & 256.0 & 227.3 & 88.7 & 256.0 \\
$747 \mathrm{~B}$ & $54^{\circ} 48.68^{\prime}$ & $76^{\circ} 47.64^{\prime}$ & 1697.2 & 6 & 50.3 & 48.9 & 97.2 & 50.3 \\
$747 \mathrm{C}$ & $54^{\circ} 48.68^{\prime}$ & $76^{\circ} 47.64^{\prime}$ & 1695.2 & 16 & 144.5 & 49.5 & 34.3 & 350.5 \\
$748 \mathrm{~A}$ & $58^{\circ} 26.45^{\prime}$ & $78^{\circ} 58.89^{\prime}$ & 1287.5 & 2 & 19.0 & 19.3 & 101.3 & 19.0 \\
$748 \mathrm{~B}$ & $58^{\circ} 26.45^{\prime}$ & $78^{\circ} 58.89^{\prime}$ & 1290.9 & 25 & 225.1 & 190.2 & 84.5 & 225.1 \\
$748 \mathrm{C}$ & $58^{\circ} 26.45^{\prime}$ & $78^{\circ} 58.89^{\prime}$ & 1290.5 & 87 & 760.0 & 185.9 & 24.5 & 935.0 \\
$749 \mathrm{~A}$ & $58^{\circ} 43.03^{\prime}$ & $76^{\circ} 24.45^{\prime}$ & 1071.5 & 1 & 9.5 & 10.0 & 105.7 & 9.5 \\
$749 \mathrm{~B}$ & $58^{\circ} 43.03^{\prime}$ & $76^{\circ} 24.45^{\prime}$ & 1069.5 & 14 & 123.8 & 64.7 & 52.2 & 123.8 \\
$749 \mathrm{C}$ & $58^{\circ} 43.03^{\prime}$ & $76^{\circ} 24.45^{\prime}$ & 1069.5 & 16 & 147.5 & 29.9 & 20.3 & 249.5 \\
$750 \mathrm{~A}$ & $57^{\circ} 35.54^{\prime}$ & $81^{\circ} 14.42^{\prime}$ & 2030.5 & $\mathbf{b}^{2}$ & 189.3 & 68.6 & 36.3 & 460.5 \\
$750 \mathrm{~B}$ & $57^{\circ} 35.52^{\prime}$ & $81^{\circ} 14.37^{\prime}$ & 2030.5 & ${ }^{\circ} 5$ & 57.4 & 24.6 & 42.9 & 709.7 \\
$751 \mathrm{~A}$ & $57^{\circ} 43.56^{\prime}$ & $79^{\circ} 48.89^{\prime}$ & 1633.8 & 18 & 166.2 & 162.9 & 98.0 & 166.2 \\
\hline
\end{tabular}

\footnotetext{
a Water depths are drill-pipe-measurement (DPM) depths corrected for the distance between the rig floor and sea level $(10.5 \mathrm{~m})$.

b Five "wash" cores were also taken.

c Twelve "wash" cores were also taken.
}

Unless stated otherwise, correlation of biostratigraphic zonations/datum events with the Geomagnetic Polarity Time Scale (GPTS) follows that of Berggren et al. (1985a, 1985b, 1985c) and Aubry et al. (1988) for the Cenozoic and that of Kent and Gradstein (1985), supplemented by the integrated magnetobiostratigraphic correlations in Berggren et al. (1983), for the Cretaceous.

\section{THE KERGUELEN PLATEAU: BACKGROUND INFORMATION}

The Kerguelen Plateau forms a broad topographic high located in the southern Indian Ocean. It is bounded to the northeast by the Australian-Antarctic Basin, to the south by the 3500 -m-deep Princess Elizabeth Trough, to the southwest by the African-Antarctic Basin, and to the northwest by the Crozet Basin (Fig. 1). The plateau stretches approximately $2300 \mathrm{~km}$ between $46^{\circ}$ and $64^{\circ} \mathrm{S}$ in a northwest-trending direction toward the Antarctic continental margin. The feature is between 200 and $600 \mathrm{~km}$ wide and stands $2-4 \mathrm{~km}$ above the adjacent ocean basins.

Most of the Kerguelen Plateau lies south of the present-day Polar Front (Antarctic Convergence) and beneath the main flow of the Antarctic Circumpolar Current (Fig. 6). Drilling on the Kerguelen Plateau, therefore, should document the development and evolution of these two oceanographic features, which have major effects on global climate and surface-water circulation.

The Kerguelen Plateau has been divided into two distinct domains (Schlich, 1975; Houtz et al., 1977). The northern portion of the plateau, also designated as the KerguelenHeard Plateau, is located between $46^{\circ}$ and $54^{\circ} \mathrm{S}$. This portion generally lies in $<1000-\mathrm{m}$ water depths, and it includes the feature's only subaerial manifestations: Kerguelen, Heard, and McDonald islands. The southern portion of the plateau, the Southern Kerguelen Plateau, located between $57^{\circ}$ and $64^{\circ} \mathrm{S}$, is deeper (water depths are generally between 1500 and $2000 \mathrm{~m}$ ) and displays a much more subdued topography.

The transition zone exhibits a complex bathymetry with a large east-trending spur, the Elan Bank, extending westward from the main plateau over a distance of $600 \mathrm{~km}$. The northeastern flank of the plateau is extremely steep and almost linear, especially to the north; the topography of the southwestern flank is more complicated, but it generally has a gentler slope.

A recent bathymetric chart, drawn at a scale of $1 / 5,000,000$ at the equator, has been jointly edited by the Bureau of
Mineral Resources, Canberra, Australia; the Institut de Physique du Globe, Strasbourg, France; and the Territoire des Terres Australes et Antarctiques Franêaises, Paris, France (Schlich et al., 1987). The chart covers the entire Kerguelen Plateau and takes into account most of the existing bathymetric data (Fig. 7). The overall morphology of the plateau, as described above, is clearly expressed; moreover, the northeastern flank of the plateau appears even steeper on this new bathymetric chart and follows almost exactly, to the north and to the south, the direction of the present Southeast Indian Ridge axis.

The age of the oceanic crust abutting the plateau varies and has been analyzed since 1966 by various authors. The Kerguelen Plateau and Broken Ridge form a symmetric pair of "aseismic ridges" separated by the Southeast Indian Ridge. Fracture zones and magnetic lineations related to this spreading center have been mapped and analyzed by Schlich and Patriat $(1967,1971 b)$, Le Pichon and Heirtzler (1968), McKenzie and Sclater (1971), Schlich (1975, 1982), and Houtz et al. (1977). To the east, north, and west the seafloor close to the Northern Kerguelen Plateau has been dated by the observed magnetic lineations (Fig. 8). The isochrons along the northeastern margin of the Kerguelen-Heard Plateau vary in age from $32 \mathrm{Ma}$ (to the north) to $42-43 \mathrm{Ma}$ (to the south). Farther to the south, the eastern flank of the Southern Kerguelen Plateau is bounded by the deep Labuan Basin (Coffin et al., 1986), which has not been dated but probably corresponds to Lower Cretaceous oceanic crust (Rotstein et al., 1990). No seafloor magnetic anomalies have been observed adjacent to the southwestern flank of the Kerguelen Plateau.

According to Le Pichon and Heirtzler (1968), the Kerguelen Plateau and Broken Ridge separated in Eocene time. The reconstructions proposed by Houtz et al. (1977) and Goslin (1981), which allow for the total closure of Australia and Antarctica at Anomaly 20, show an unacceptable overlap of Broken Ridge and the Northern Kerguelen Plateau, considering the oldest sediments that were recovered by coring and drilling on these two features (Quilty, 1973; Luyendyk and Davies, 1974). Mutter and Cande (1983) and Mutter et al. (1985), employing a revised chronology for the breakup of Australia and Antarctica (Cande and Mutter, 1982), partially resolved the overlap problem. However, the resulting reconstruction does not exclude an overlap of the northern portion of the Kerguelen Plateau with Broken Ridge.

The crustal structure of the Southern Kerguelen Plateau was modeled by Houtz et al. (1977), who used gravimetric and 


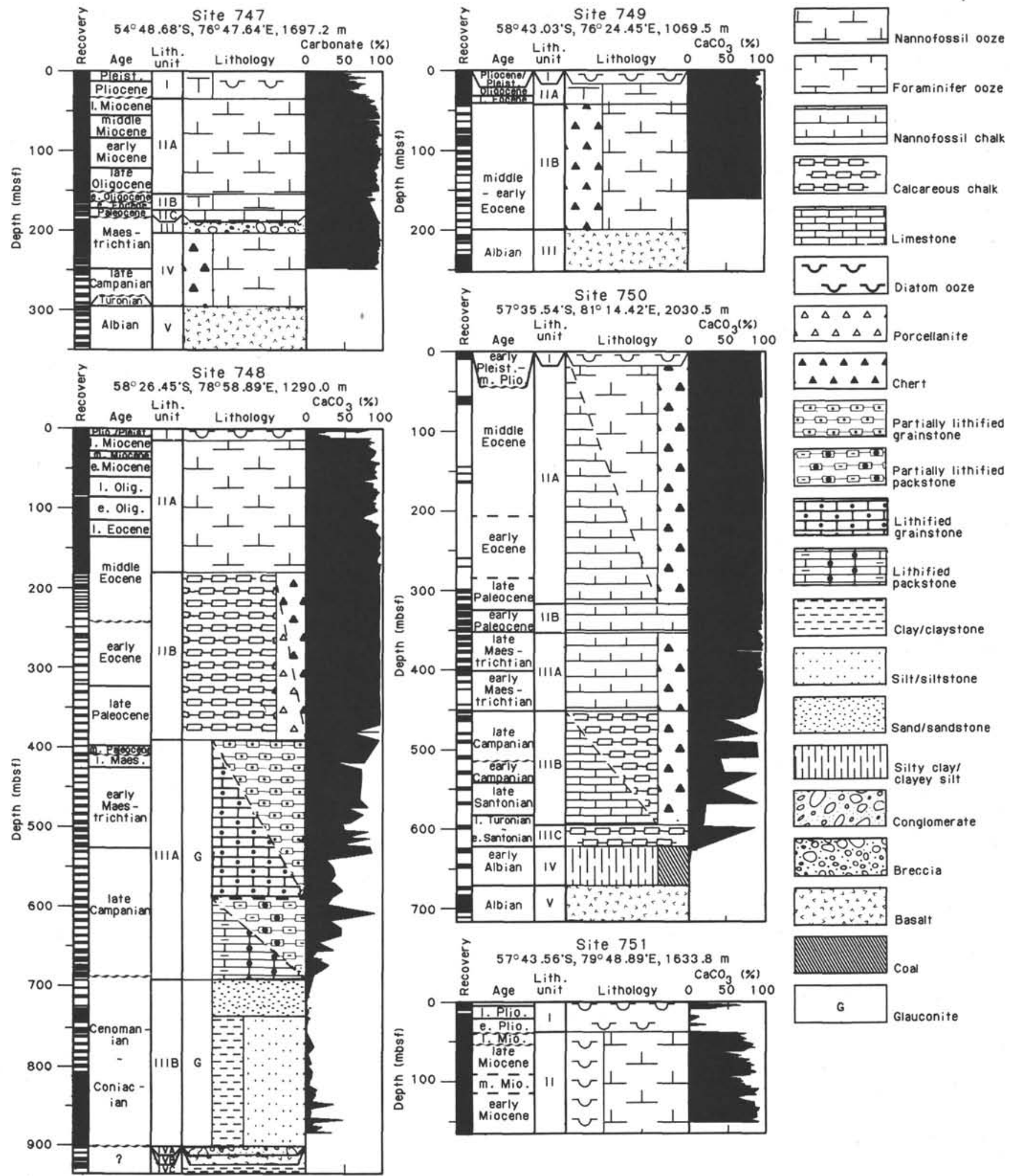

Figure 2. Stratigraphic columns for Leg 120 drill sites showing recovery, ages, lithologic units, lithologies, and percent carbonate. 


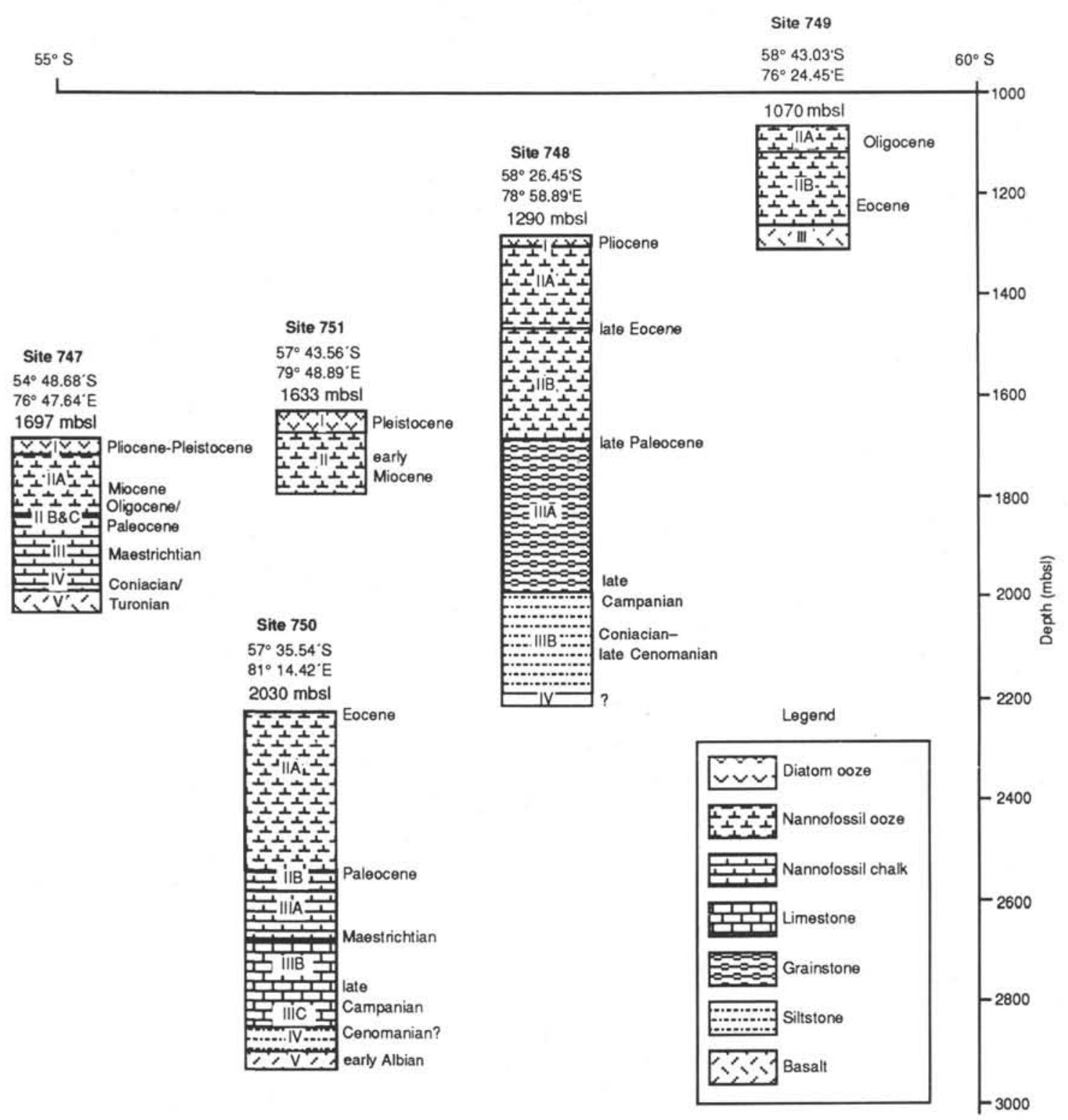

Figure 3. Leg 120 sites arranged according to water depth and latitude.

seismic reflection/refraction data, and that of the KerguelenHeard Plateau by Recq et al. (1983) and Recq and Charvis (1986), who used two refraction profiles shot on Kerguelen Island. The maximum thickness of the crust was determined to lie between 15 and $23 \mathrm{~km}$. Furthermore, the seismic velocity vs. depth distribution is similar to that of typical oceanic islands (Crozet) or plateaus (Madagascar). More recently, Recq and Charvis (1987) proposed an interpretation based upon gravimetric measurements on Kerguelen Island and upon GEOS 3 and SEASAT altimetric data. They used a Pratt-type compensation model with a compensation depth at $50 \mathrm{~km}$ and concluded that the Kerguelen Plateau and its symmetric feature, Broken Ridge, originated near a spreading center by excessive volcanism related to a thermal anomaly in the lithosphere beneath Kerguelen Island.

Bradley and Frey (1988) have analyzed the MAGSAT data associated with the Kerguelen Plateau and Broken Ridge. Assuming for their model that the two features are structurally similar and underlain by oceanic crust, they concluded that the Curie isotherm rises to a depth of about $15 \mathrm{~km}$ within the crust to the north beneath Kerguelen and Heard islands. This result supports the suggested thermal anomaly (Recq and Charvis, 1987).

\section{Recent Geophysical and Geological Surveys}

American, Soviet, French, and Australian research ships have surveyed the Kerguelen Plateau, and these results are summarized by Schlich, Wise, et al. (1989, "Introduction" chapter, pp. 7-23). The most recent contributions are from the French Marion Dufresne $(1981,1983,1986)$ and the Australian Rig Seismic (1985) cruises. Among these, the 1983 Marion Dufresne cruise (MD35) provided 42 piston cores and 3 dredge hauls located on the eastern and western flanks of the Kerguelen-Heard Plateau at a latitude of about $50^{\circ} \mathrm{S}$ (see Schlich, Wise, et al., 1989 , pp. 7-23, for sample numbers and locations of these and other recovered materials referred to here).

The 1985 Rig Seismic cruise (RS02) acquired high-quality multichannel seismic reflection (MCS) data over the Kerguelen Plateau between $50^{\circ}$ and $60^{\circ} \mathrm{S}$. Most of the lines were shot in a west-southwest to east-northeast direction; the 


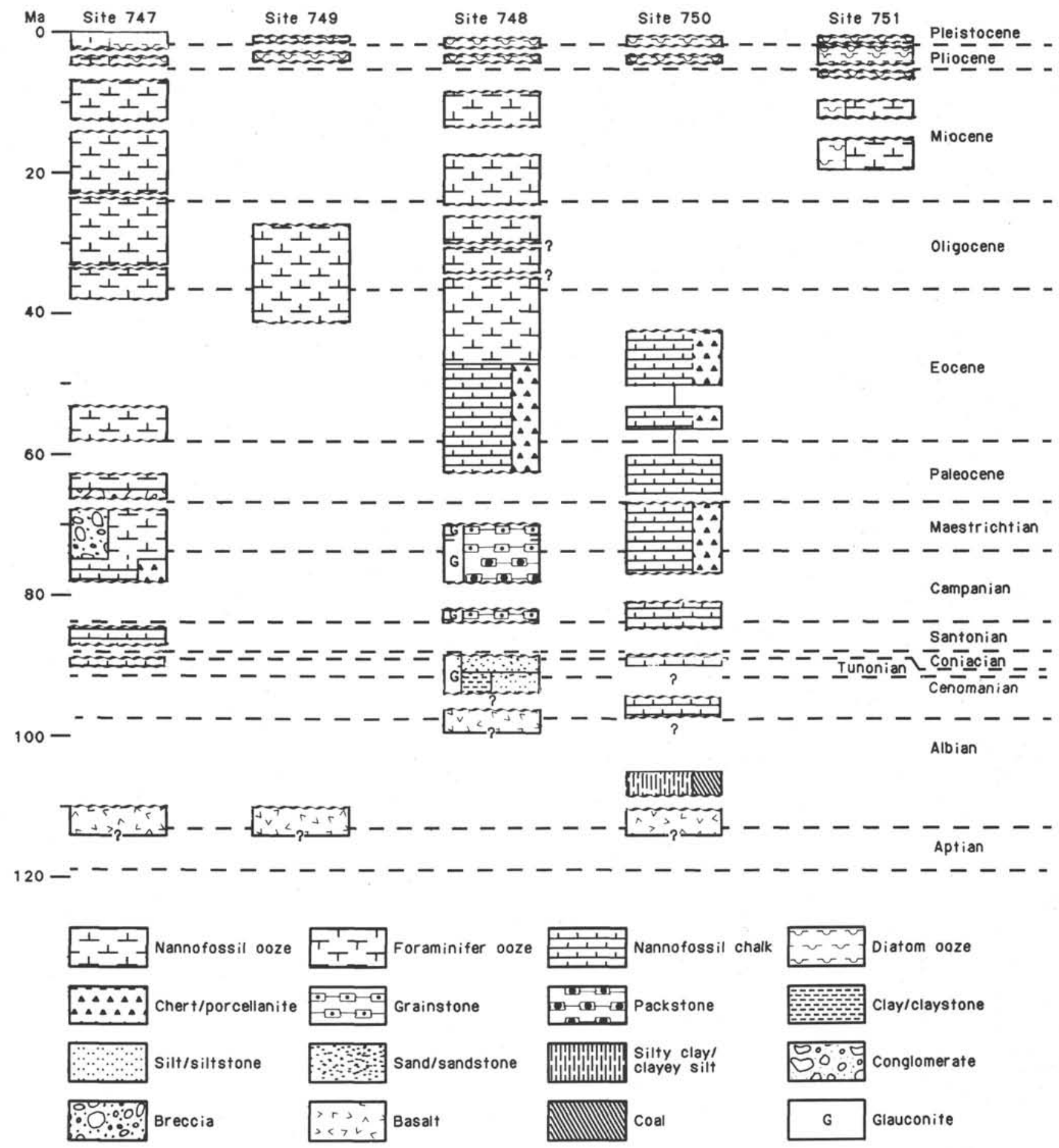

Figure 4. Simplified stratigraphy for Leg 120 sites.

spacing of these profiles on the Southern Kerguelen Plateau was roughly $50 \mathrm{~km}$. A total of $5600 \mathrm{~km}$ of 48 -channel seismic reflection profiles was obtained (Fig. 9). One sonobuoy experiment was performed during this cruise along Line RS02-29. Minor sampling was undertaken over a prominent fault scarp, the $77^{\circ} \mathrm{E}$ Graben; two of these recovered a few samples of igneous rocks.

The first 1986 Marion Dufresne cruise (MD47) surveyed the entire Southern Kerguelen Plateau between $55^{\circ}$ and $63^{\circ} \mathrm{S}$ and provided $4450 \mathrm{~km}$ of 24 -channel seismic reflection pro- files. The profiles shot in the central part of the Southern Kerguelen Plateau were arranged to be orthogonal to the 1985 Rig Seismic lines (Fig. 9). Four successful sonobuoy experiments were performed during this cruise over representative sedimentary sequences.

The second 1986 Marion Dufresne cruise (MD48) provided 16 piston cores and 8 dredge hauls located along the eastern flank of the Kerguelen-Heard Plateau and on the central part of the Southern Kerguelen Plateau. All the piston core and dredge sites were selected on the basis of the multichannel 


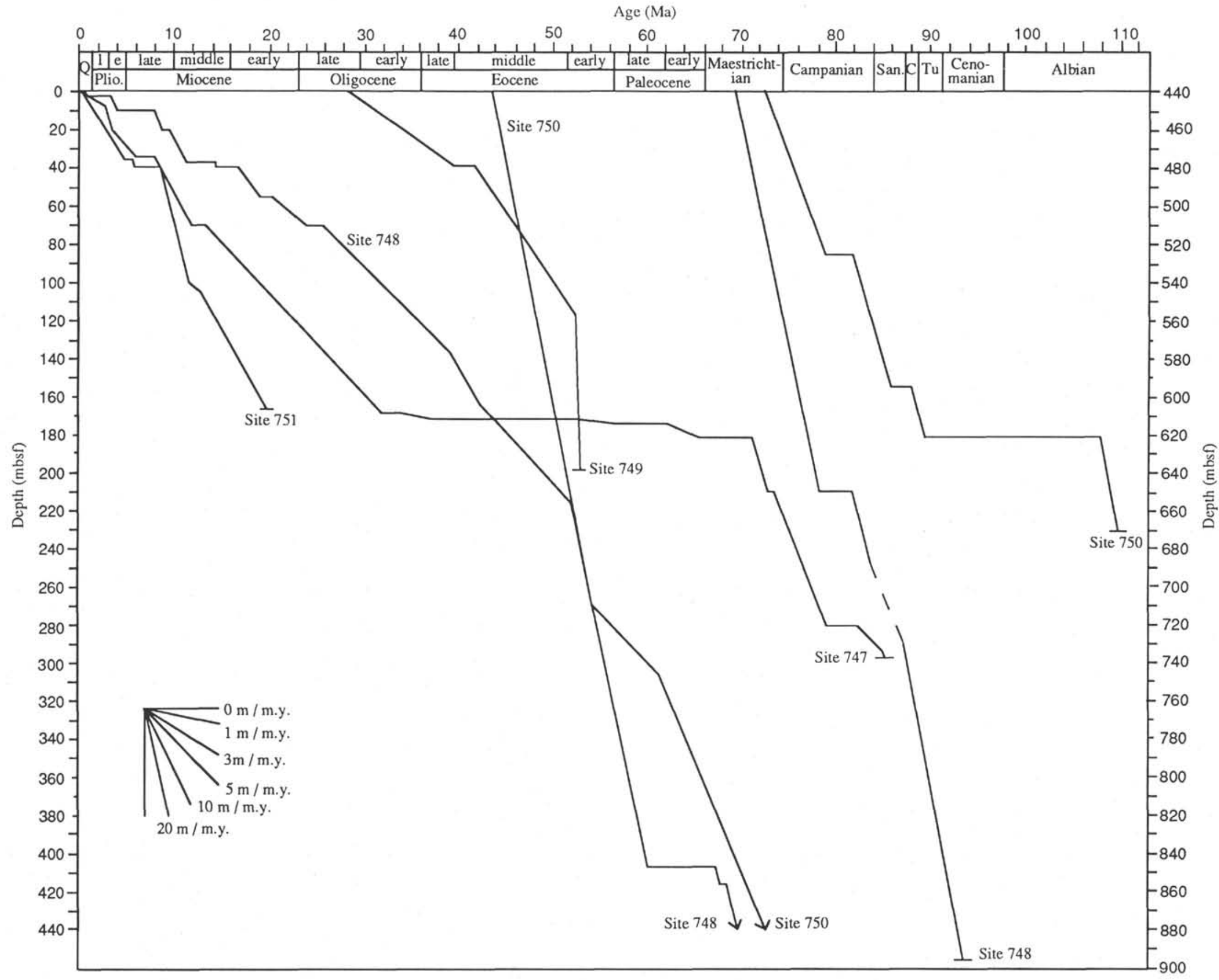




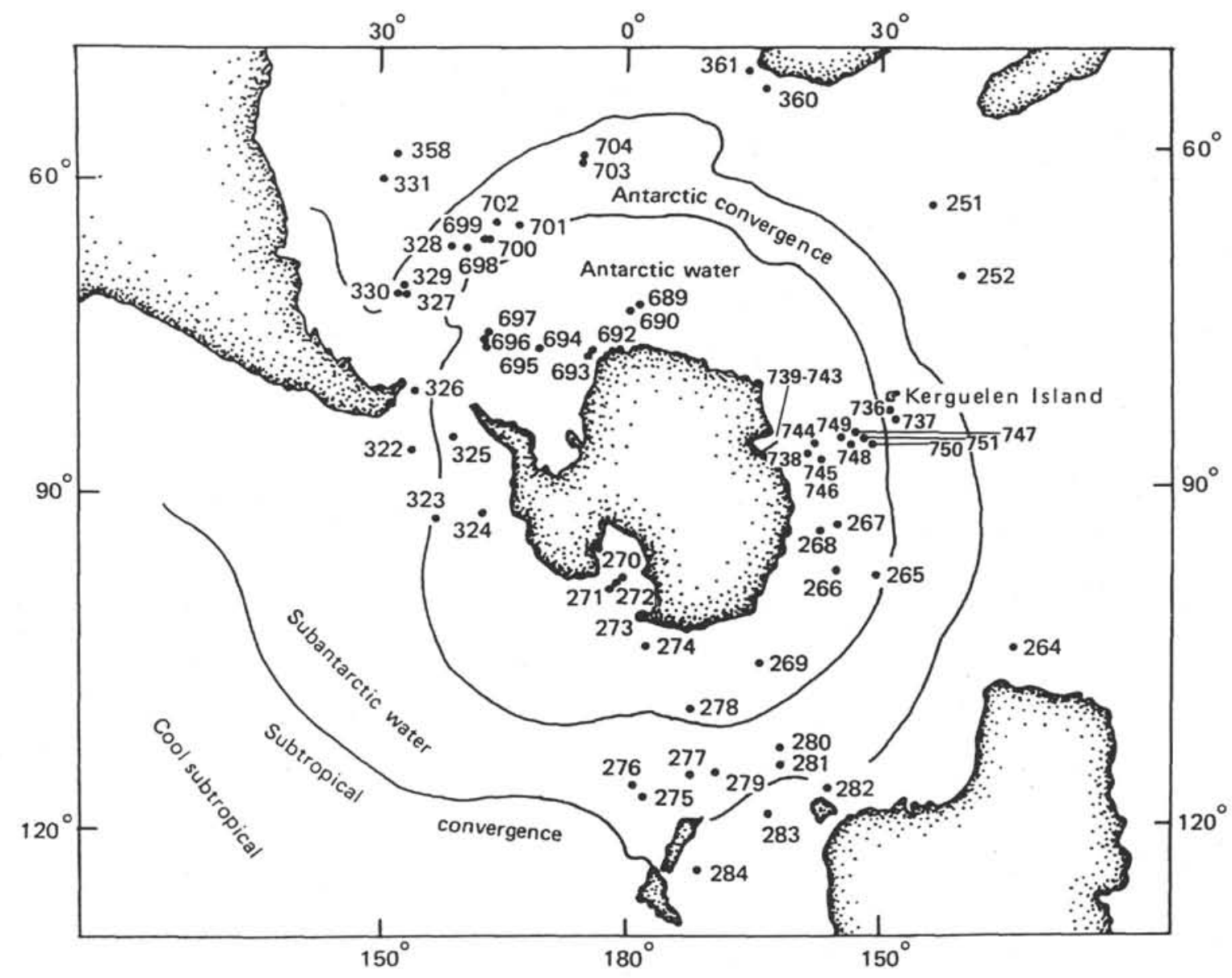

Figure 6. Present-day location of surface-water masses of the Southern Ocean (Kennett, 1978). Numbers indicate Deep Sea Drilling Project (DSDP) and Ocean Drilling Program (ODP) sites.

seismic reflection profiles obtained during the 1985 Rig Seismic cruise and the 1981 and 1986 Marion Dufresne cruises.

\section{The Structure and Evolution of the Kerguelen-Heard Plateau}

The structure of the Kerguelen-Heard Plateau and the sediment distribution were first described by Schlich et al. (1971), Schlich (1975, 1982), and Houtz et al. (1977). The average sediment thickness in the basin located southeast of Kerguelen Island is about $2000-2500 \mathrm{~m}$ with a maximum of $3000 \mathrm{~m}$. The evolution of the Kerguelen-Heard Plateau, postulated from basin stratigraphy and based upon piston-core age determinations (Wicquart, 1983; Wicquart and Fröhlich, 1986) has been summarized by Munschy and Schlich (1987) as follows:

The Kerguelen-Heard Plateau was created between 130 and $110 \mathrm{Ma}$ at or near an active spreading center in the gap between the Antarctic-Australia and India plates. From the early Late Cretaceous (about $100 \mathrm{Ma}$ ) to the Eocene (45-42 $\mathrm{Ma}$ ), the plateau was a shallow marine structure continuously subsiding at a rate of about $20 \mathrm{~m} / \mathrm{m}$.y. and covered by pelagic and shelf sediments. At 45-42 Ma, the KerguelenHeard Plateau and Broken Ridge was separated by seafloor spreading at the Southeast Indian Ridge. From 45-42 Ma to the Miocene, a major gap of sedimentation occurred. Later the plateau was covered by pelagic sediments, interbedded with clastic sedimentary layers originating from Kerguelen Island.

\section{The Structure and Evolution of the Southern Kerguelen Plateau}

The structure of the Southern Kerguelen Plateau and the sediment distribution were first described by Houtz et al. (1977) and were based upon geophysical and geological data collected by Eltanin in 1971 and 1972. Three recent research cruises, Rig Seismic 02 (1985) and Marion Dufresne 47 and 48 (1986), yielded new information for understanding the structure and evolution of the Southern Kerguelen Plateau (Ramsay et al., 1986; Coffin et al., 1986, 1990; Leclaire et al., 1987a, 1987b; Schlich et al., 1988; Colwell et al., 1988).

The Southern Kerguelen Plateau is characterized by several large basement uplifts and is affected by multiple stages of normal faulting and possibly strike-slip faulting (Fig. 10). The most striking feature, the north-trending $77^{\circ} \mathrm{E}$ Graben, delineated by Houtz et al. (1977) in the northwestern part of the southern plateau, extends from $55^{\circ}$ to almost $58^{\circ} \mathrm{S}$. To the east, the Southern Kerguelen Plateau is delineated by fault scarps of high relief that are flanked by a large abyssal plain, the Labuan Basin (Ramsay et al., 1986).

From an analysis of the SEASAT-derived, free-air gravity field and the seismic reflection data, Coffin et al. (1986) concluded that the Southern Kerguelen Plateau may be an amalgamation of disparate structural elements, including broad crustal uplifts, continental fragments, and possible fracture zone ridges and troughs. Other striking features, clearly expressed to the south, are basement highs that divide 
INTRODUCTION

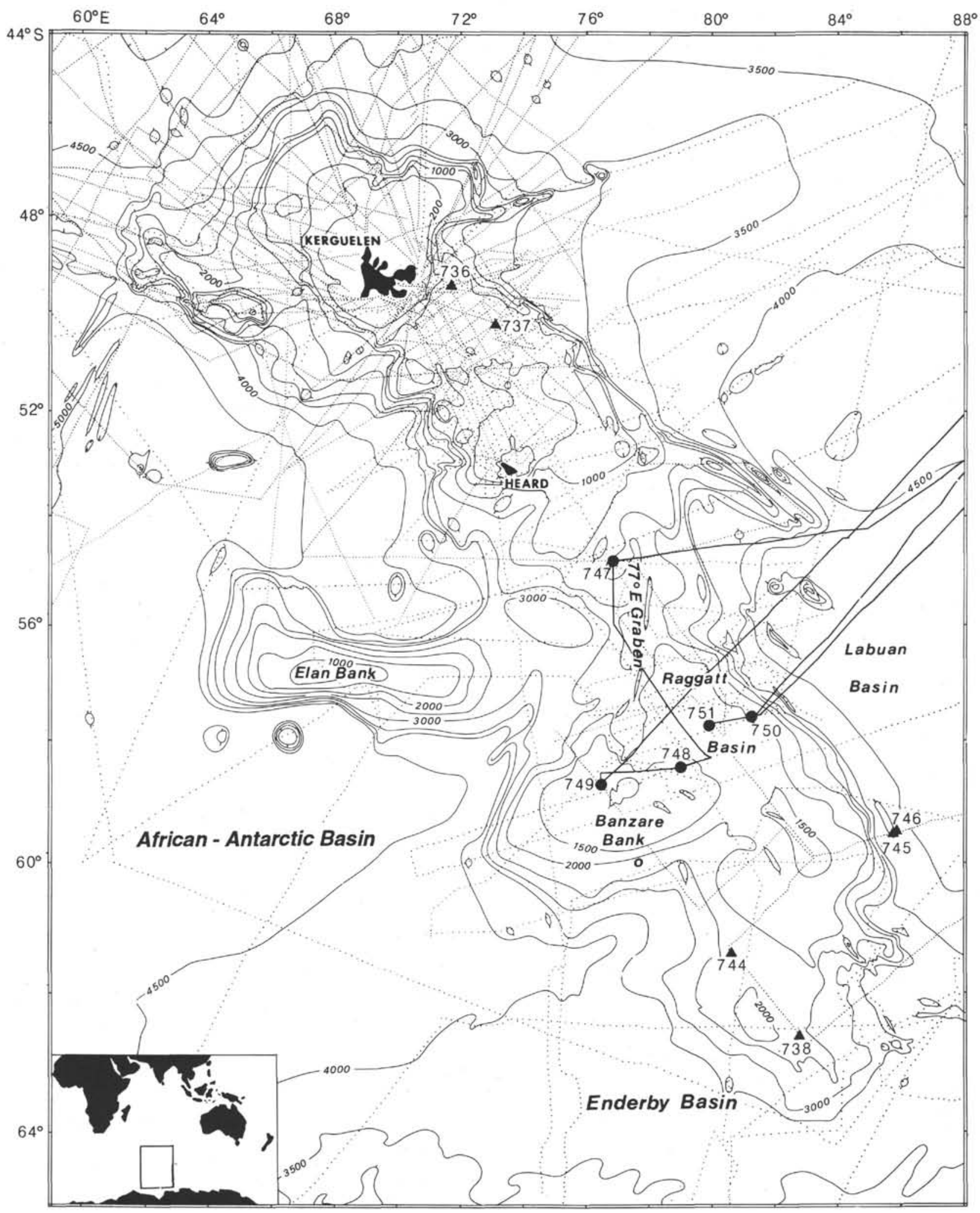

Figure 7. Bathymetric chart of the Kerguelen Plateau after Schlich et al. (1987). The contour interval is $500 \mathrm{~m}$. 


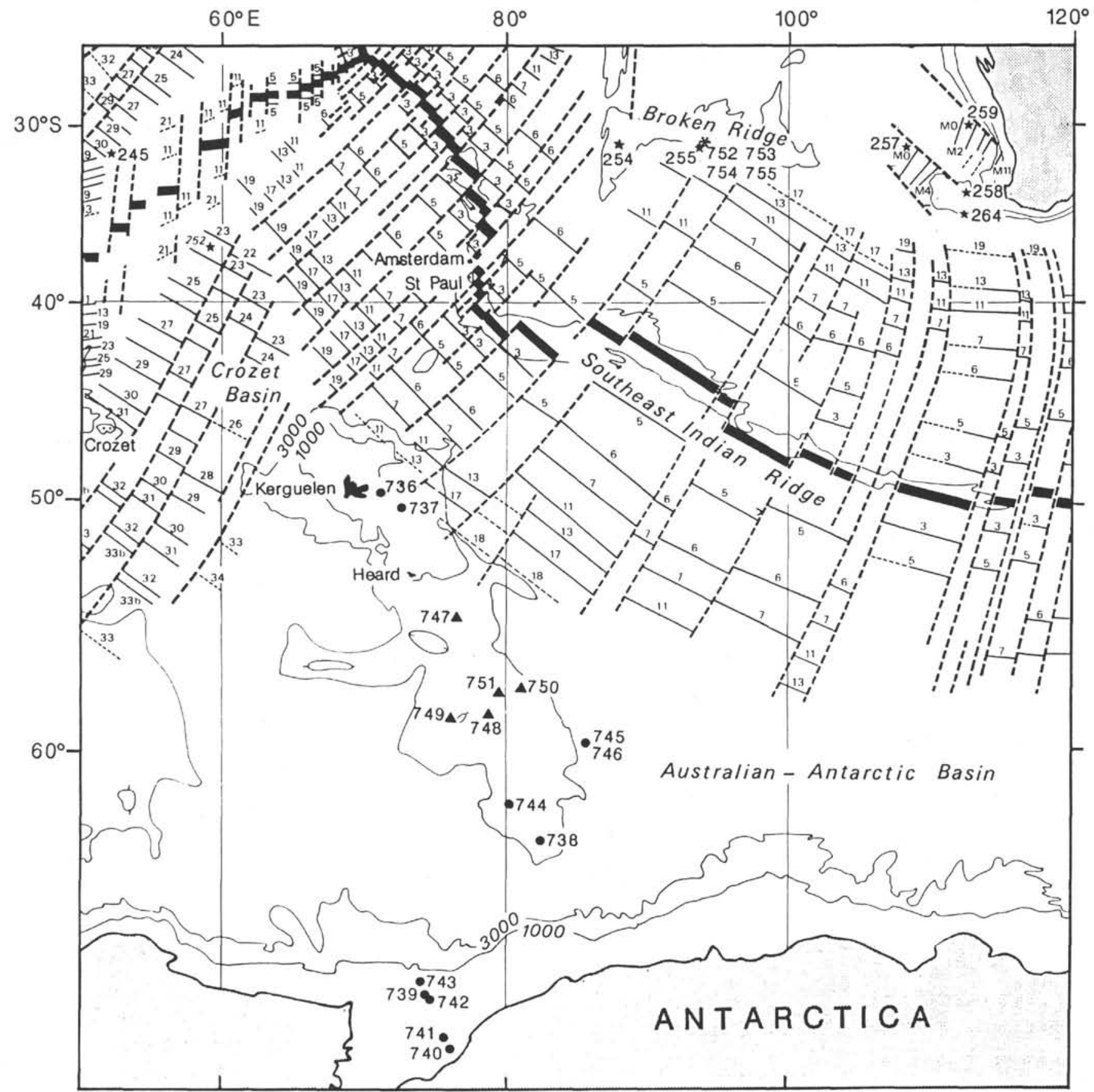

Figure 8. Location map of the Kerguelen Plateau and Broken Ridge in the south central Indian Ocean. Fracture zones and magnetic lineations are from Schlich and Patriat (1967, 1971a, 1971b), Le Pichon and Heirtzler (1968), Schlich (1975, 1982), and Houtz et al. (1977). Symbols for ODP sites as in Figure 1; stars = DSDP sites.

the central and southern parts of the Southern Kerguelen Plateau into several distinct sedimentary domains. The most developed sedimentary basin is the large Raggatt Basin to the east.

Dredging along the $77^{\circ} \mathrm{E}$ Graben recovered the first significant assemblage of basement rocks from the Southern Kerguelen Plateau (Leclaire et al., 1987a, 1987b). The horst samples are basaltic and are chemically and isotopically of oceanic-island affinity rather than ridge affinity; a K/Ar age of the basalt is about $114 \mathrm{Ma}$, corresponding to the Aptian Stage of the Early Cretaceous (Leclaire et al., 1987a). The lower- most exposed sediments are of Late Cretaceous to Paleogene age and are separated from the upper Eocene to Oligocene calcareous nannofossil oozes and Neogene to Pleistocene calcareous and siliceous oozes by a horizon of interbedded cherts (Leclaire et al., 1987b).

The sediment thickness in the Raggatt Basin on the Southern Kerguelen Plateau is about $2500-3000 \mathrm{~m}$. Based upon a preliminary analysis of the 1985 Rig Seismic data and the 1986 Marion Dufresne data, Colwell et al. (1988) and Schlich et al. (1988) independently identified six seismic sequences. By joint interpretation of the Australian and French multichannel 
INTRODUCTION

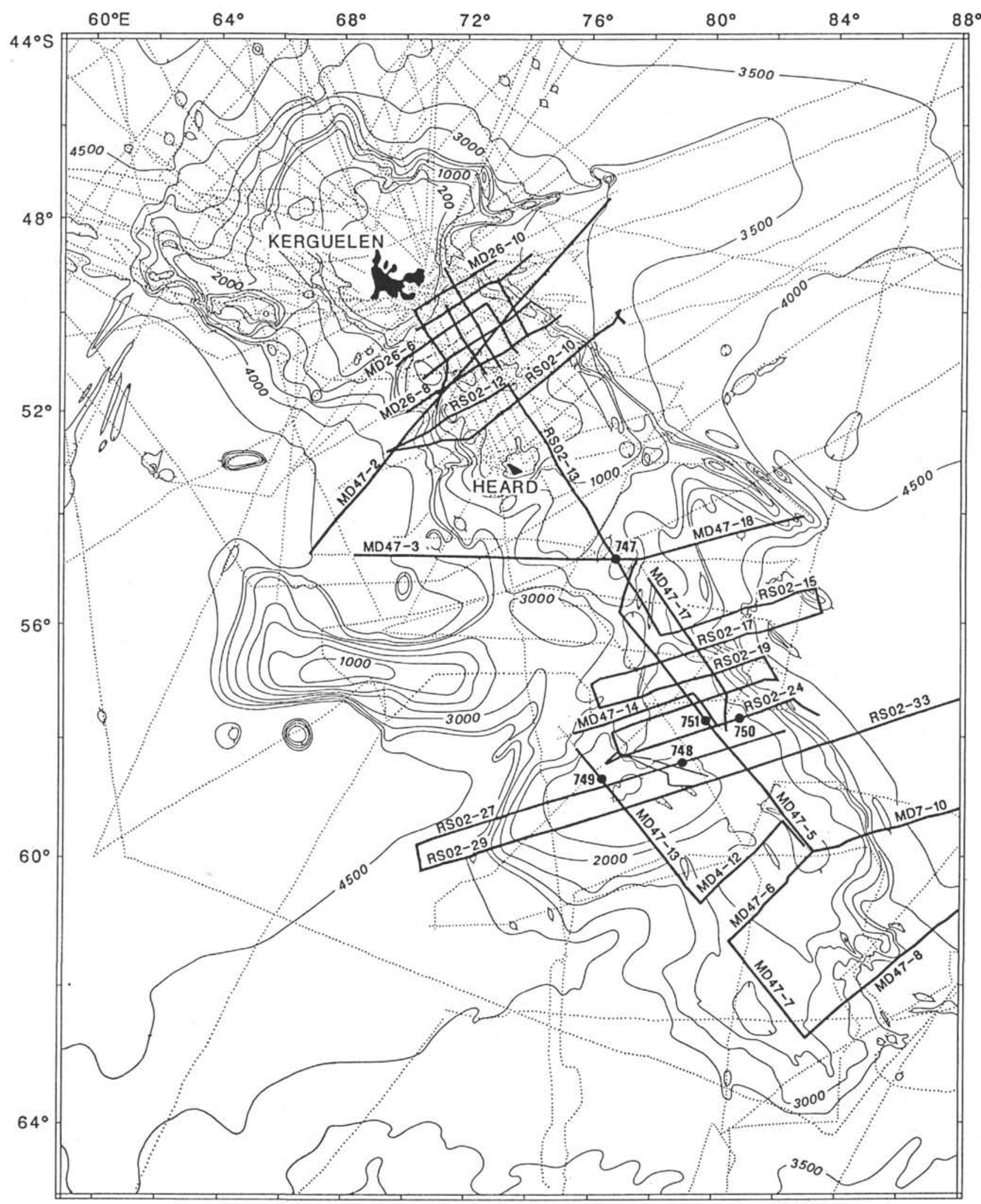

Figure 9. Track lines on the Kerguelen Plateau. Bold lines denote MD26 (1981), RS02 (1985), and MD47 (1986) multichannel seismic reflection profiles. Leg 120 drill sites are illustrated by large dots. 


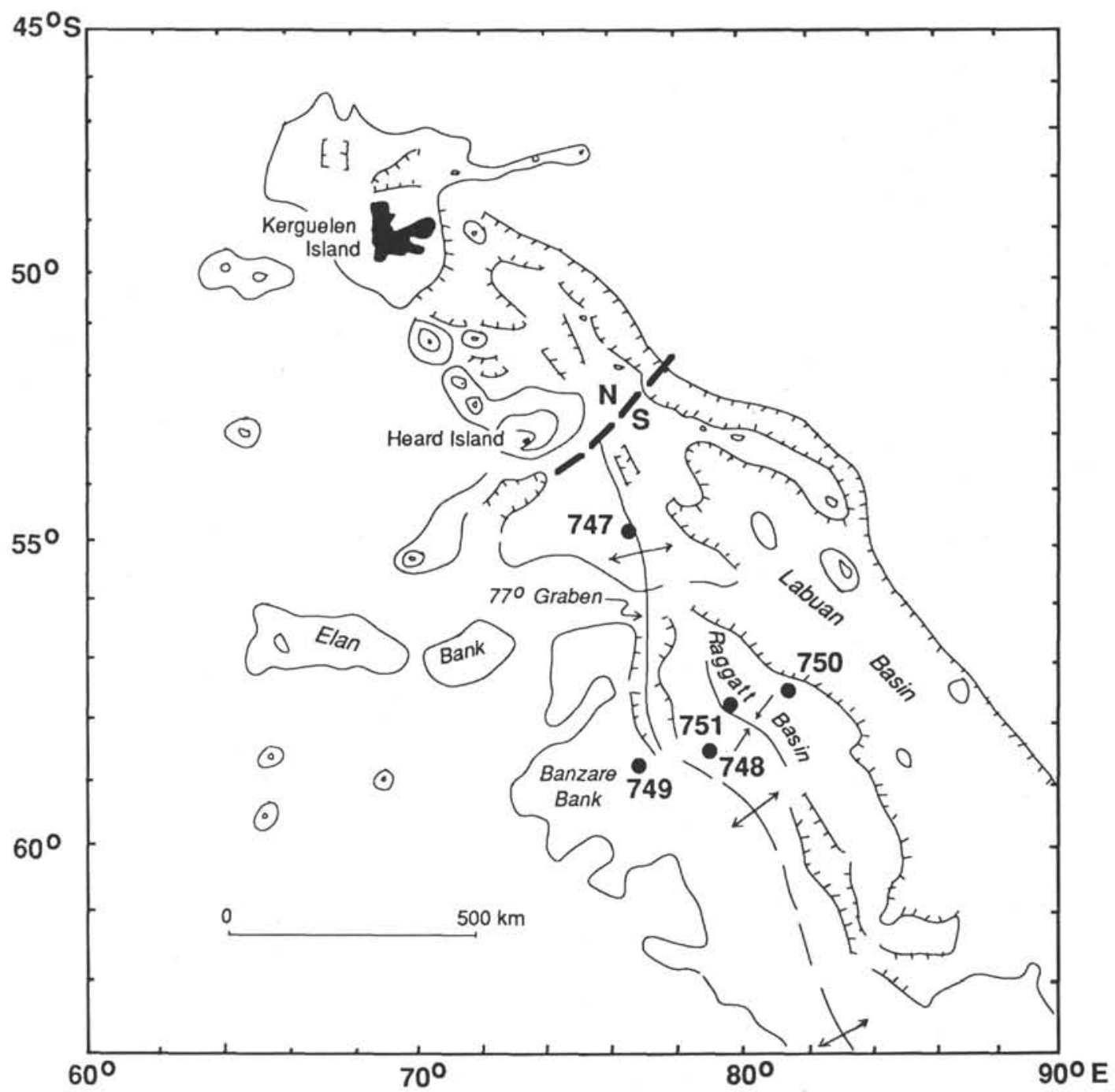

Figure 10. Morphotectonic map of the Kerguelen Plateau. Scarp symbols indicate moderate to steep gravity gradients, in some cases coinciding with normal faults. N/S = boundary between northern and southern sectors. Anticline symbol indicates axis of broad arch of southern sector, and syncline symbol indicates axis of Raggatt sedimentary basin.

seismic reflection profiles, Coffin et al. (1990) distinguished in the Raggatt Basin seven seismic sequences overlying a basement complex of Early Cretaceous age (Fig. 11). The underlying basement complex is characterized by two types of seismic images: nonreflective acoustic basement with poor internal reflectors associated with elevated basement ridges and reflective layered basement with clear internal reflectors associated with volcanic lava flows (Schaming and Rotstein, 1990). During the Early Cretaceous the basement was eroded close to sea level.

The Raggatt Basin developed through local subsidence and was progressively filled up by Seismic Sequences K1 and K2 of shallow-water facies followed by a thick Seismic Sequence $\mathrm{K} 3$ of mixed shallow-water and open-marine facies (Fig. 11). In some places, Seismic Sequence K3 exhibits a mounded upper surface. At the end of the Late Cretaceous, the western part of the Raggatt Basin was uplifted and general faulting affected the plateau. This event probably marks the rifting between the Southern Kerguelen Plateau and the Diamantina Zone. During the early Paleocene, pelagic sedimentation dominated the entire plateau and Seismic Sequence P1 draped the newly shaped basin while the depocenter of the Raggatt Basin shifted to the northeast. From the late Paleocene to the Present, the Raggatt Basin continuously subsided and was progressively filled up by a thick pelagic Sequence P2, mainly Eocene in age, and by two post-Eocene pelagic Sequences PN1 and NQ1. The latter are thinner and more limited in areal extent than the underlying sequences. The separation of the Kerguelen Plateau and Broken Ridge occurred while Sequence P2 was deposited.

\section{SITE-BY-SITE OBJECTIVES}

The site-by-site objectives stated here as well as the site summaries to follow are given by site in the order drilled. As all sites had equal (highest) priority, the drilling order was determined primarily by logistical considerations.

Site 747 (Schlich, Wise, et al., 1989, pp. 89-156; Figs. 12 and 13), located in the transition zone between the Northern and Southern Kerguelen Plateau, was the northernmost site drilled during Leg 120 . The prime objective of drilling was to determine the nature and age of the basement and to compare the results with the data obtained at other Southern Kerguelen 
INTRODUCTION

SW

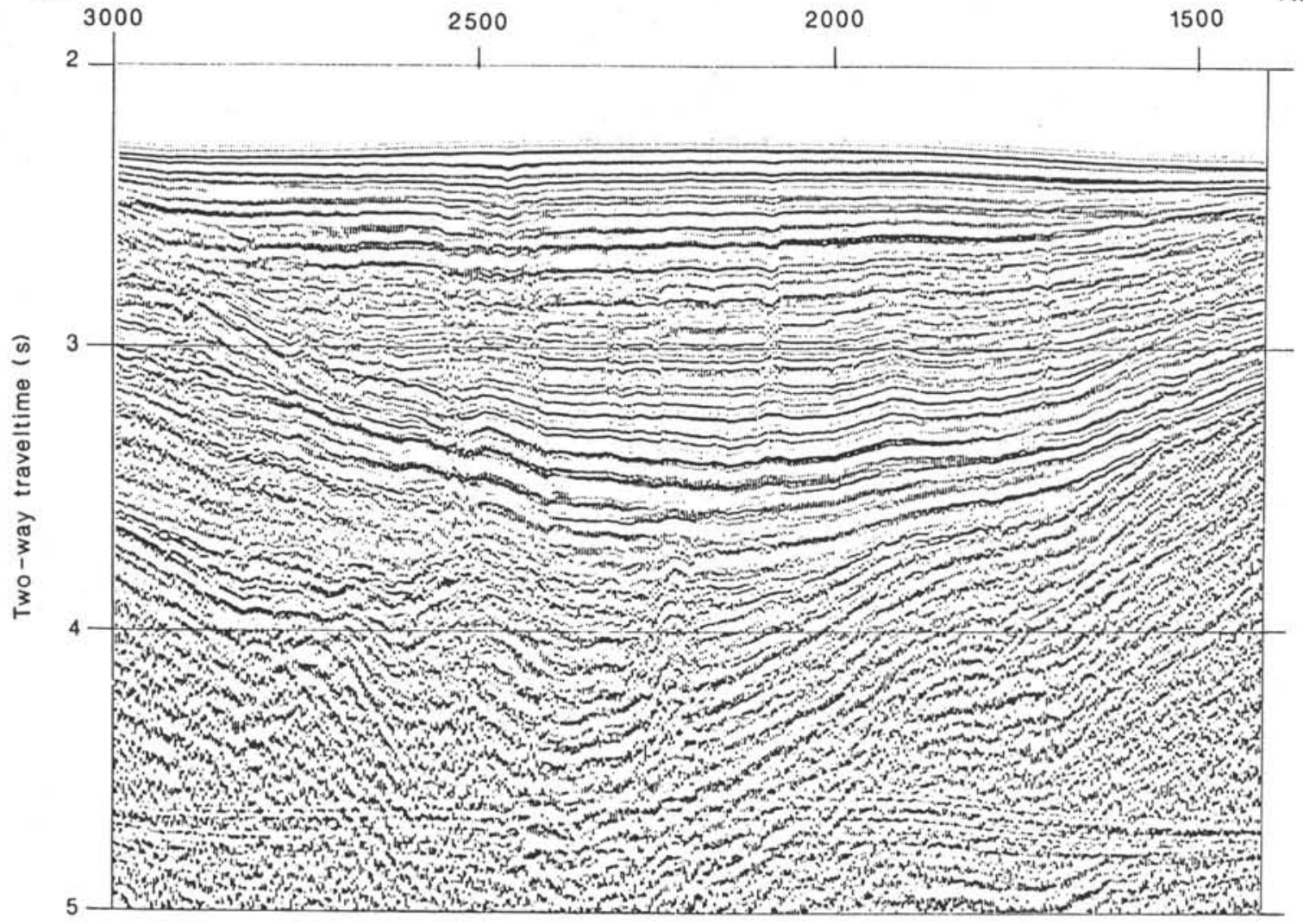

NE

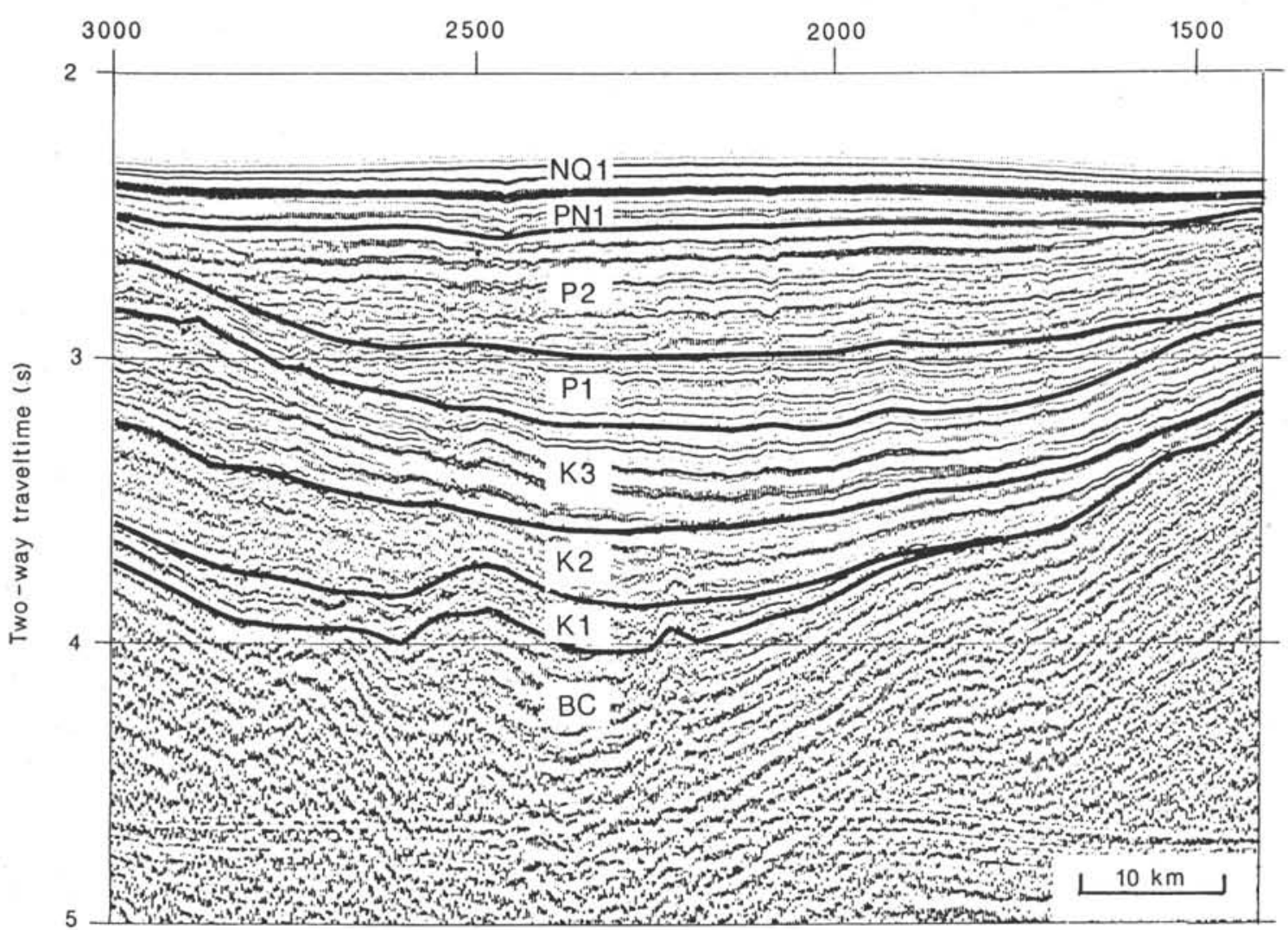

Figure 11. Northeast-southwest transect of the Raggatt Basin on the Southern Kerguelen Plateau (Seismic Profile RS02-27). The seismic sequences as defined by Schlich, Wise, et al. (1989, pp. 7-23) and Coffin et al. (1990) are shown in the figure and discussed in the text. 


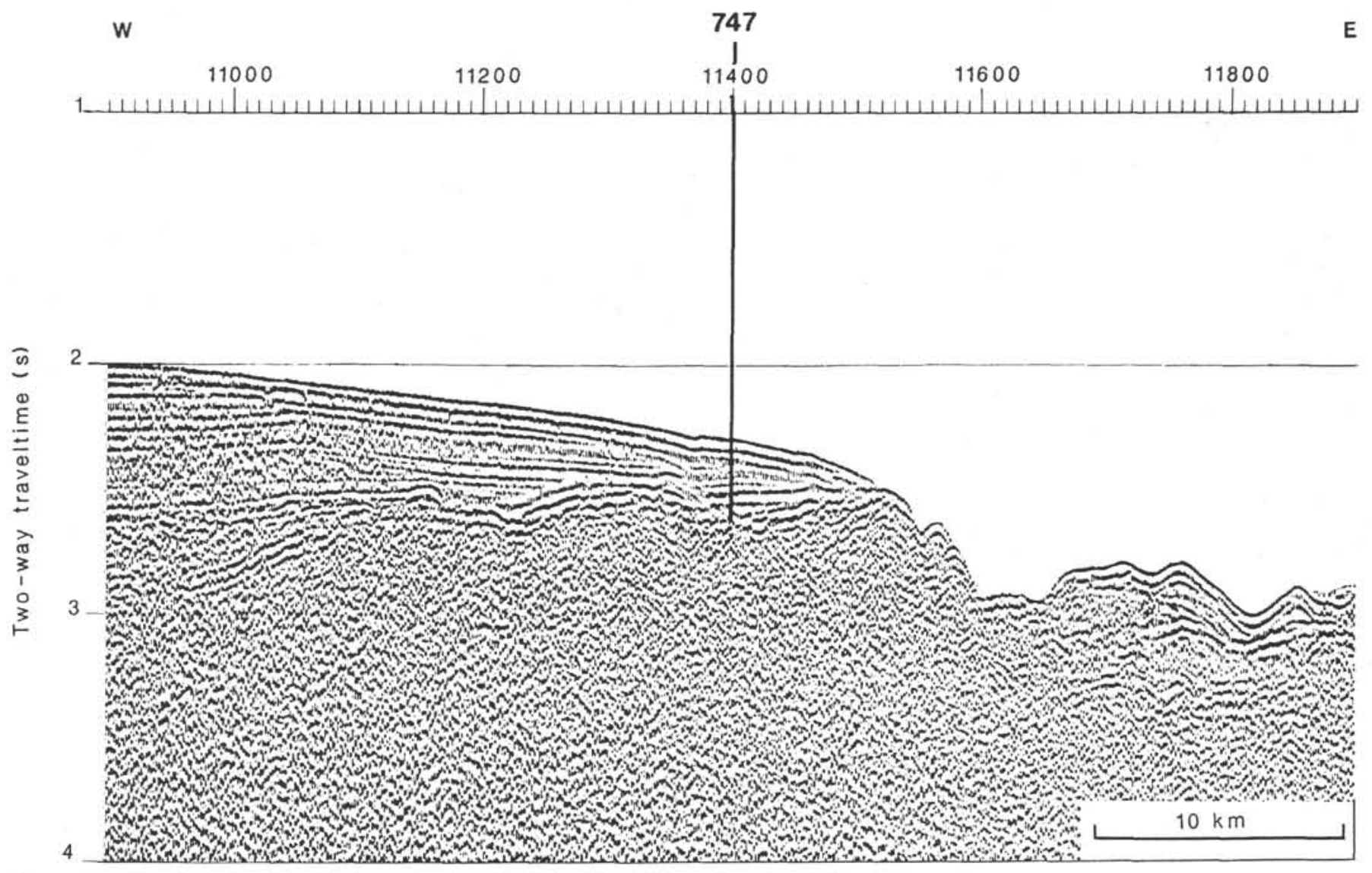

Figure 12. Seismic section MD47-03 (shot points 10900-11900) and location of Site 747.

Plateau basement sites (Leg 119, Site 738; Leg 120, Sites 749 and 750). A second objective was to study the paleoceanographic history of the region as this site, in about $1700 \mathrm{~m}$ of water, could yield carbonate sections suitable for stable isotope studies. It might be possible to trace movements of the Antarctic Convergence through time by studies of lithologic changes as well as of microfossil assemblages. In this respect, Site 747 at $55^{\circ} \mathrm{S}$ latitude provides a key transitional link between Leg 119 Sites 736 and 737 at about $50^{\circ} \mathrm{S}$ to the north and the other Leg 119 and 120 sites on the plateau to the south between $58^{\circ}$ and $63^{\circ} \mathrm{S}$. Finally, the possibility of sampling older (Paleogene, Cretaceous) sediments could provide important information about the tectonic history of the Kerguelen Plateau.

Site 748 (Schlich, Wise, et al., 1989, pp. 157-235; Fig. 14) is located on the Southern Kerguelen Plateau in the western part of the Raggatt Basin at a water depth of $1290 \mathrm{~m}$. The prime objective was to recover an expanded section of Paleogene and Cretaceous sediments reflecting the early tectonic history of the Southern Kerguelen Plateau (i.e., the ages of the different sedimentary sequences, unconformities, rifting episodes, and vertical movements) and the evolution of Cretaceous and Paleogene climates. A second objective was to recover basement samples from the Raggatt Basin and to compare these with the other sites that encountered basement on the plateau.

Site 749 (Schlich, Wise, et al., 1989, pp. 237-275; Fig. 15) was scheduled as the primary dedicated basement site of the Kerguelen Plateau drilling program. With a sedimentary cover of only $200 \mathrm{~m}$ on the western flank of Banzare Bank, it offered the best opportunity for a deep penetration (of at le'st $200 \mathrm{~m}$ ) to obtain basement rocks from the Southern Kerguelen Plateau. The prime objective of drilling was to determine the nature and age of the Kerguelen Plateau basement (is it a continental fragment, oceanic island basalt, or mid-ocean ridge basalt?).

Site 750 (Schlich, Wise, et al., 1989, pp. 277-337; Fig. 16) is located in the eastern part of the Raggatt Basin so as to recover an expanded section of Cretaceous sediments reflecting the early tectonic history of the Southern Kerguelen Plateau (age of the sediments and unconformities, rifting episodes, vertical movements) as well as the evolution of the Cretaceous paleoenvironments. Site 750 was drilled as a companion site to Site 748 located in the western Raggatt Basin and was selected to complement the Cretaceous and Paleocene tectonic history of the Kerguelen Plateau. A second objective was to recover true basement samples from the Raggatt Basin and to compare these with those from the three other Leg 119 and 120 sites that recovered true basement (Sites 738, 747, and 749).

Site 751 (Schlich, Wise, et al., 1989, pp. 339-373; Fig. 17), at a water depth of $1634 \mathrm{~m}$ in the central Raggatt Basin, was chosen to yield an expanded, high-resolution Neogene and Paleogene stratigraphic section deposited above the calcium carbonate compensation depth and well south of the presentday Polar Front. Combined with other Leg 119 and 120 Neogene sites, this site represents a key component of a meridional paleoceanography transect. Because of logistical constraints, we limited drilling to the Neogene objective.

\section{SITE SUMMARIES}

\section{Site 747}

Site $747\left(54^{\circ} 48.68^{\prime} \mathrm{S}, 76^{\circ} 47.64^{\prime} \mathrm{E}\right.$; water depth, $\left.1697.2 \mathrm{~m}\right)$ lies in the transition zone between the Northern and Southern 


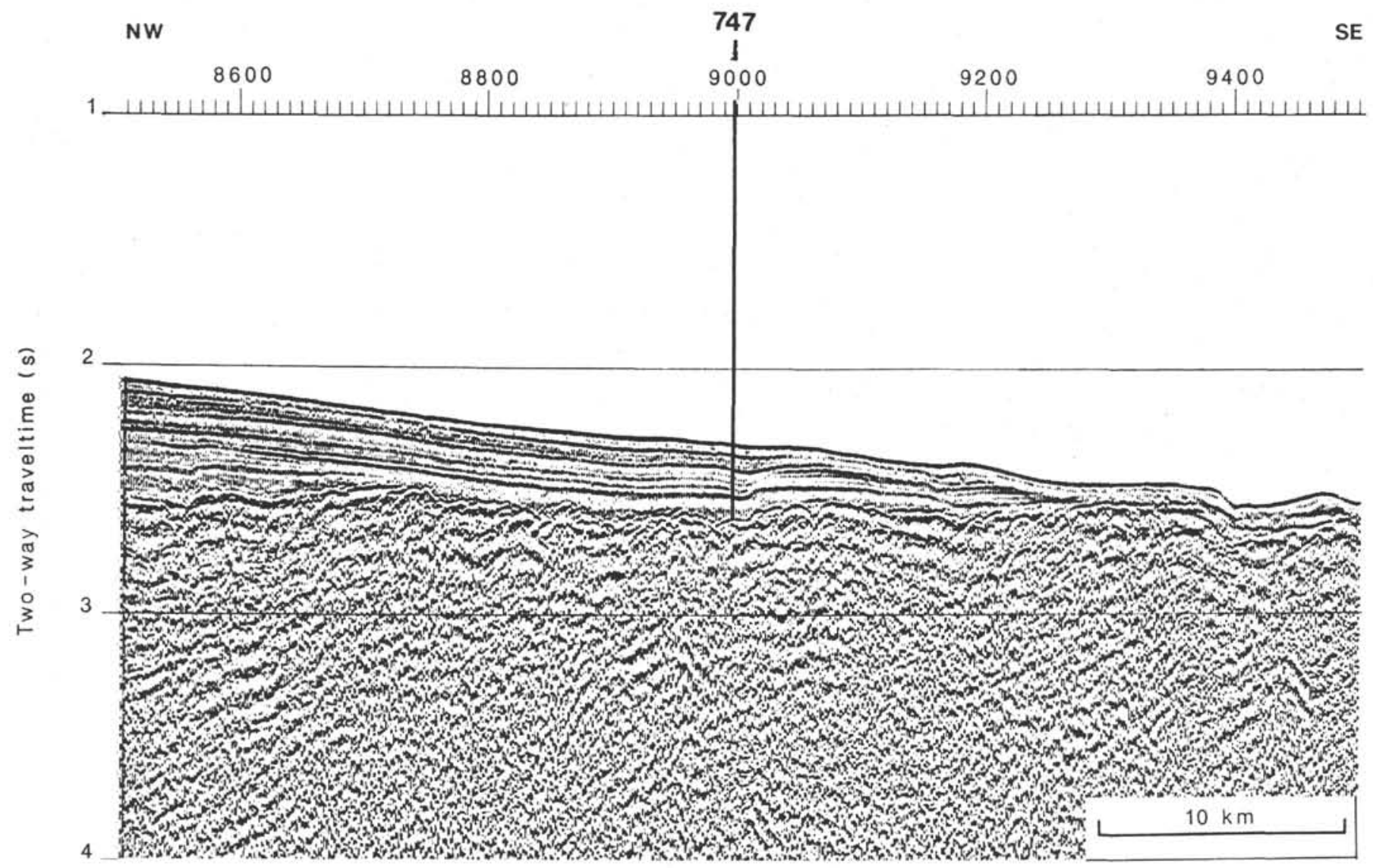

Figure 13. Seismic section RS02-13 (shot points 8510-9500) and location of Site 747.

Kerguelen Plateaus approximately $500 \mathrm{~km}$ south of the Polar Front (Antarctic Convergence). The site was located close to the intersection of multichannel seismic (MCS) Lines MD47-03 and RS02-13 (Figs. 9 and 12). A 296.5-m-thick Turonian-Coniacian through Pleistocene pelagic sedimentary section and $53.9 \mathrm{~m}$ of underlying basalt were cored in three holes with various combinations of advanced hydraulic piston corer (APC), extended core barrel (XCB), and rotary core barrel (RCB) coring. Although located beneath the presentday Antarctic Water Mass, the sediments contain carbonate virtually throughout the section except for Maestrichtianlower Paleocene volcaniclastic sands, breccias, and cobbles. The latter denote a major episode of uplift and erosion at this location on the plateau.

Lithologic units recognized at Site 747 are well illustrated in the "Frontispiece" (this volume) and are as follows:

Unit I (0-32.7 mbsf): Pleistocene to lower Pliocene foraminifer diatom oozes with minor ice-rafted debris and dropstones prevalent only in the upper $20 \mathrm{~m}$, whereas occasional vitric ash layers occur throughout.

Unit II (32.7-181.9 mbsf): upper Miocene to Paleocene nannofossil ooze and chalk divisible into three subunits.

Subunit IIA (32.7-151.5 mbsf): upper Miocene and upper Oligocene nannofossil ooze with occasional vitric ash layers.

Subunit IIB (151.5-170.5 mbsf): upper Oligocene to lower Eocene nannofossil chalk with foraminifers with hardgrounds near the base (169 mbsf).

Subunit IIC (170.5-181.9 mbsf): highly bioturbated lower Eocene to Paleocene nannofossil chalk, with large (centimeter-scale) burrows and occasional shallow-water fossils (e.g., bivalve fragments and larger benthic foraminifers) and a hardground 173.1 mbsf in Section 120-747A-19X-2, 109-130 cm (see "Frontispiece," this volume).

Unit III (181.9-189.5 mbsf): lower Paleocene-upper Maestrichtian multicolored, volcaniclastic, polygenetic sand, breccia, and cobbles with probable intercalated chalk layers (Section 120-747C-4R-CC; see "Frontispiece," this volume).

Unit IV (189.5-295.1 mbsf): upper Maestrichtian to Turonian-Coniacian nannofossil chalk and thin nodular chert layers. Lower Maestrichtian chalks exhibit faint to pronounced and colorful horizontal laminations with brittle phosphate seams in Section 120-747A-21X-4 (see "Frontispiece," this volume).

Unit V (296.6-350.5 mbsf): basalt flows composed of variably brecciated, veined, and altered aphyric to sparsely phyric basalts (e.g., Section 120-747C-16R-3; see "Frontispiece," this volume). There was a $1.5-\mathrm{m}$ gap between the lowermost sediment and the basalt.

The sequence documents a succession of tectonic and paleoceanographic events that highlight the geologic and tectonic evolution of the Kerguelen Plateau (Fritsch et al., this volume, Chapter 49; Munschy et al., this volume, Chapters 47 and 51). Vesicular basalt flows deposited in a shallow-water to subaerial environment capped the basement structure of the plateau before its subsidence and the accumulation of marine sediment, which began at this site by late Turonian-early Coniacian times. The oldest sediments recovered are shallowwater glauconitic calcarenites with admixtures of fine volcanic debris eroded from the basement. These are overlain disconformably by deeper water middle Campanian to Maestrichtian 


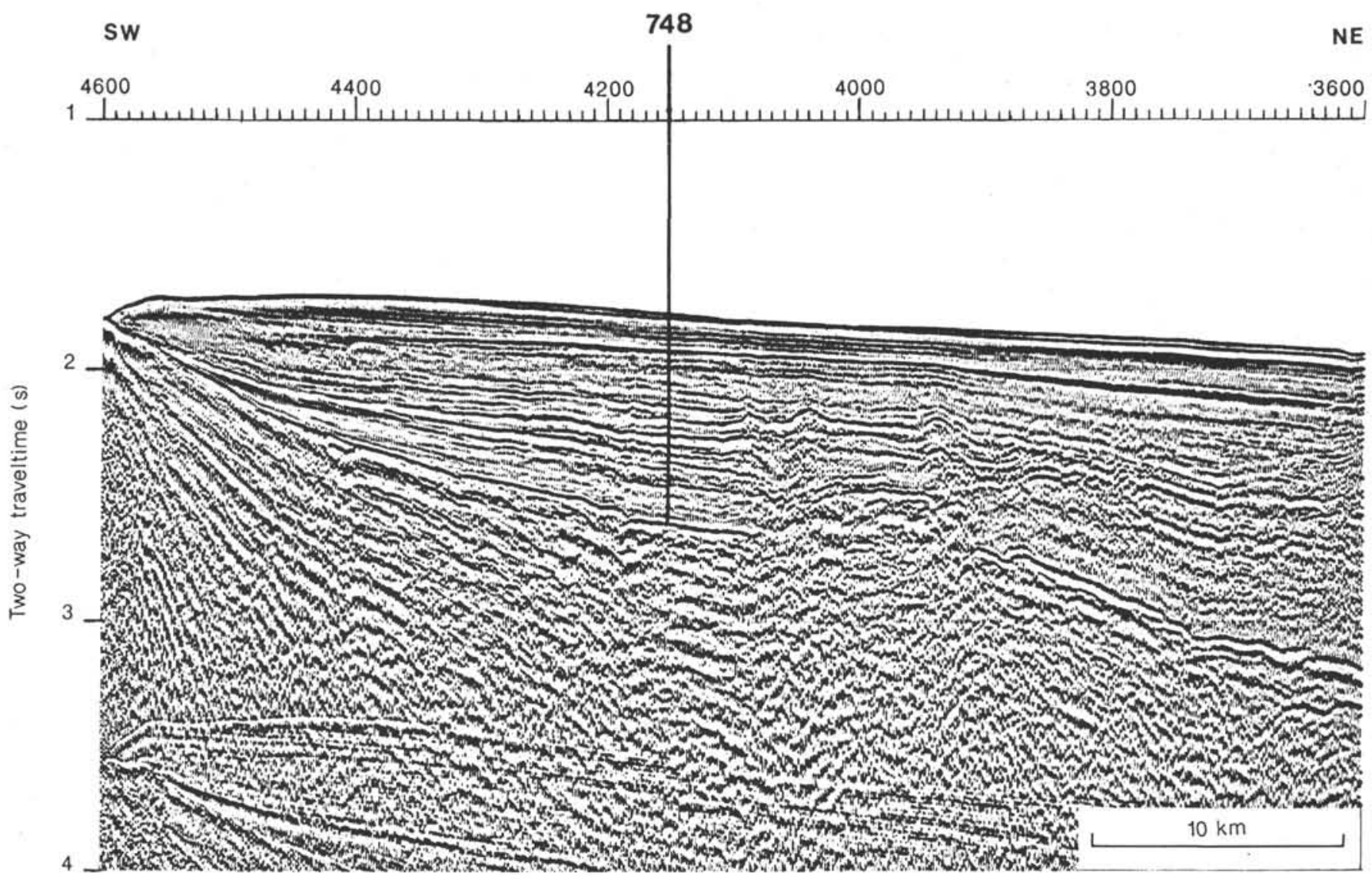

Figure 14. Seismic section RS02-27 (shot points 3600-4600) and location of Site 748.

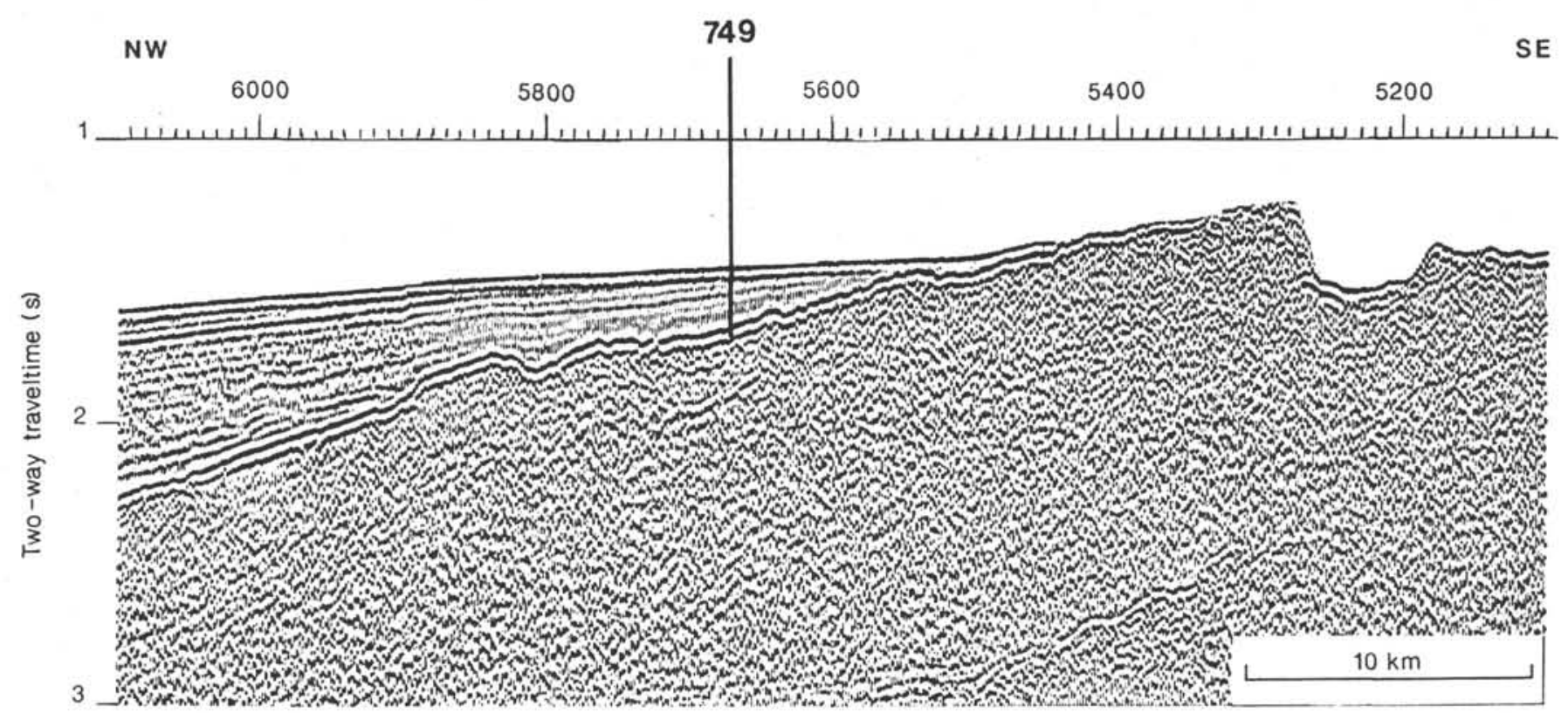

Figure 15. Seismic section MD47-13 (shot points 5100-6100) and location of Site 749.

chalks with chert stringers and some Inoceramus and pelagic crinoid remains.

The succession is interrupted by a series of Maestrichtianlower Paleocene debris flows consisting of clay-, sand-, and cobble-size clastics and breccias (see "Frontispiece," this volume; see also Schlich, Wise, et al., 1989, pp. 146-153) eroded subaerially from volcanic basement during what appears to have been a major tectonic event that affected much of the plateau. Debris flows include angular clasts of previously lithified Campanian chalk and chert that indicate substantial faulting of the seafloor. Uppermost Maestrichtian to lowermost Danian sediments are missing, but scattered vol- 


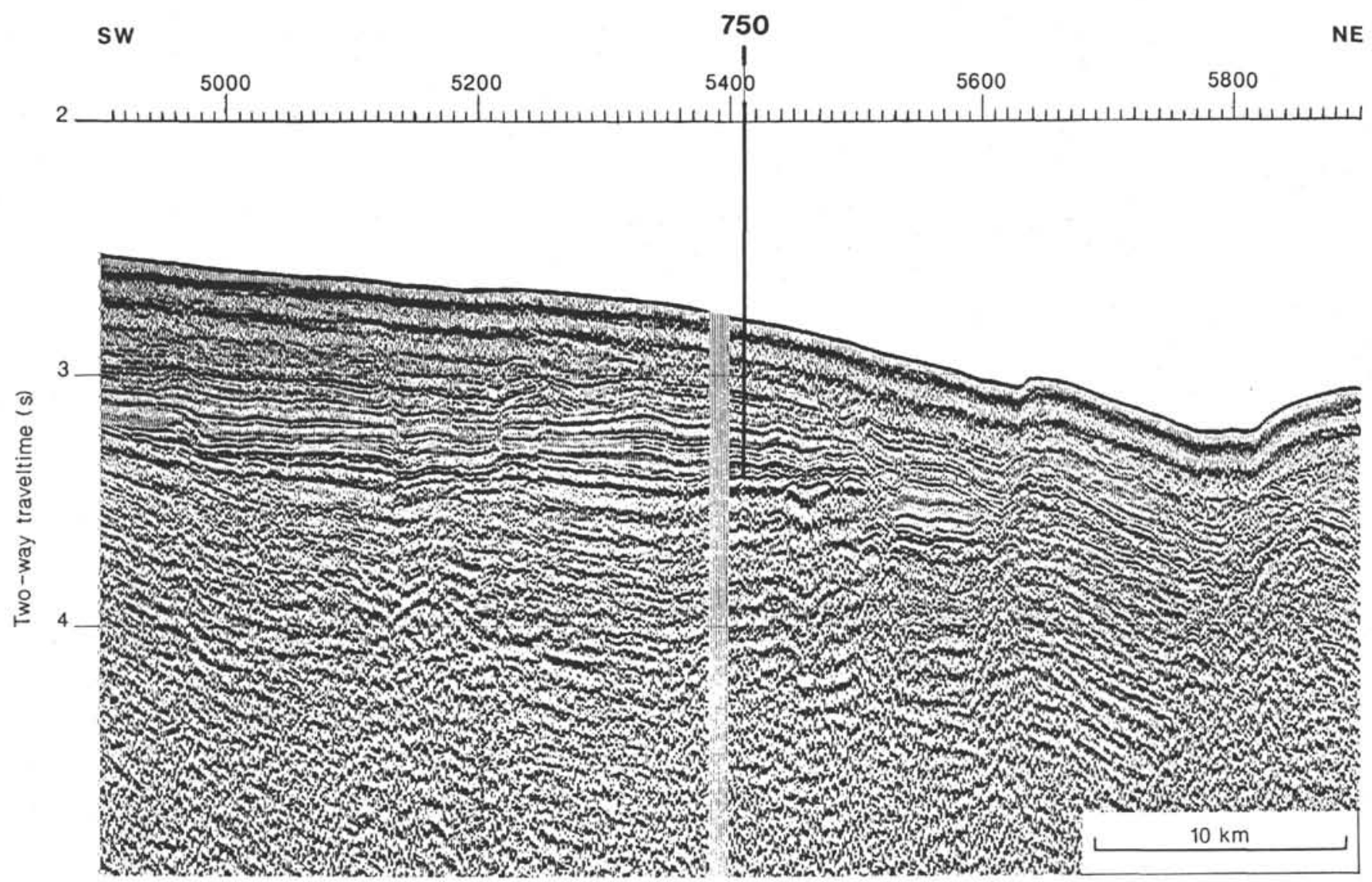

Figure 16. Seismic section RS02-24 (shot points 4900-5900) and location of Site 750.

canic debris was shed into the overlying heavily bioturbated Danian chalks.

The remaining Paleocene-lower Oligocene section is highly condensed and cut by three disconformities in which most or all of the upper Paleocene, middle to lower upper Eocene, and a small portion of the upper lower Oligocene are missing. Hardgrounds (see "Frontispiece," this volume) are developed on two of these surfaces. Sedimentation rates for the remainder of the Neogene are remarkably constant at about $5 \mathrm{~m} /$ m.y., and sedimentation for this interval appears to have been reasonably continuous through the late Pleistocene. Although the predominance of biosiliceous ooze throughout the Pliocene-Pleistocene denotes the presence of the Antarctic water mass over this site, several species of both planktonic foraminifers and calcareous nannoplankton lived in the surface waters. The top of the section is the only site drilled during Leg 120 that is dated as latest Pleistocene to possibly Quaternary in age (Wei and Wise, this volume).

The rather continuous calcareous upper Oligocene to upper Pleistocene record at a site this far south of the present-day Polar Front was unexpected, and this section serves as an important reference section for integrated high-latitude calcareous and siliceous microfossil biostratigraphy correlated with magnetostratigraphy, lower latitude zonations, and species events (see Abelemann and Lazarus; Aubry; Berggren, Chapters 31 and 35; Harwood and Maruyama; Lazarus; Li and Banner; MacKensen; MacKensen and Berggren; McCartney and Harwood; Wei and Wise, Chapters 28 and 29; Wei et al., Chapter 55; all of these chapters appear in this volume and are summarized by Harwood et al., also in this volume). As detailed by Heider et al. (this volume), a good paleomagnetic polarity record was obtained down to the lower/upper Oligocene contact.

Excellent preservation of planktonic and benthic foraminifers has allowed a complementary stable isotope stratigraphy to be established (Wright and Miller, this volume). Also noteworthy is the pristine preservation of the Danian calcareous microfossils. As described by Quilty (this volume, Chapter 22) and Watkins (this volume), the Campanian-Maestrichtian planktonic foraminifers and calcareous nannofossil assemblages belong to the cool-water austral faunal province and Falkland Plateau floral provinces, respectively. CampanianMaestrichtian sedimentation rates were a high $20 \mathrm{~m} / \mathrm{m}$.y. (Fig. 5), the result of increased productivity of calcareous and siliceous plankton coupled with a rather shallow depositional environment.

Based on macroscopic observations, the recovered basement rock consists of approximately 15 separate basalt flows. The separate flows appear compositionally similar and consist of dominantly aphyric, sparsely plagioclase-pyroxene phyric, and olivine-plagioclase phyric basalts. The flows are vesicular, indicating deposition in a shallow-water to subaerial environment. All volcanic rocks exhibit variable degrees of brecciation, veining, and alteration. The alteration minerals are described by Sevigny et al. (this volume), and these consist of zeolites, clays (celadonite and smectites) and calcite filling in veins, vesicles, and amygdules. Fresh material recovered from three flows yielded radiometric dates on the basement complex (Whitechurch et al., this volume). Trace element and isotopic chemistry, described by Salters et al. (this volume) is similar to transitional mid-ocean ridge basalt (T-MORB). 


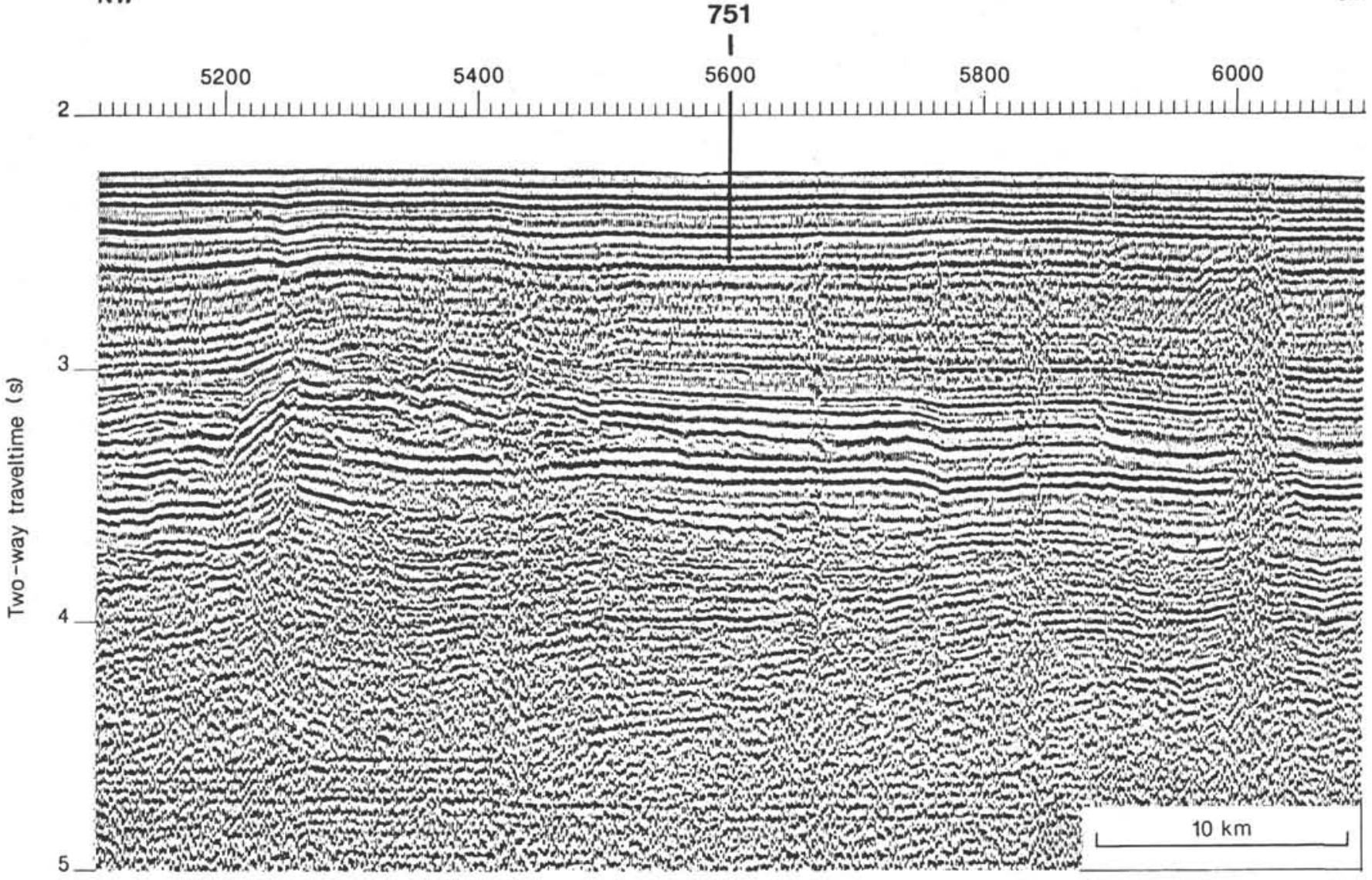

Figure 17. Seismic section MD47-05 (shot points 5100-6100) and location of Site 751.

The sequence below 90 mbsf was successfully logged despite gale force winds. The resistivity and natural gamma ray logs clearly delimit the major altered and less altered zones in the basement complex (which had been cored with only $38 \%$ recovery because of the high seas). The logs also detected basalt-breccia debris flows in the lower Maestrichtian that were not cored or only partially cored during drilling. In addition, the logs were quite effective in detecting the volcanic ash layers in the Cenozoic pelagic sequences of lithologic Unit 2, and these could be correlated among the various Leg 119,120 , and 121 sites drilled on the Kerguelen Plateau and Broken Ridge (Pratsen and Anderson, this volume). The petrology, geochemistry, and chronology of these tephra layers are described by Bitschene et al. (this volume) and Morche et al. (this volume). An important goal of these studies is to lay the groundwork for a Cenozoic tephrostratigraphy for the region.

The seismic sections (MD47-03 and RS02-13) and the lithologic units were correlated on board using essentially uncorrected velocities measured on cores. At this stage, basement was identified with a reflector located between 0.33 and $0.37 \mathrm{~s}$ two-way traveltime (TWT), and the top of lithologic Unit III was associated with a major reflector at $0.22-0.24 \mathrm{~s}$ TWT. Based upon a synthetic seismogram computed after correction of the Schlumberger velocity log and correction of the measured core velocities for the unlogged interval, Fritsch et al. (this volume, Chapter 49) propose a more precise and detailed correlation among the seismic sections, the different lithologic units, and the seismic sequences identified in the Raggatt Basin (Schlich, Wise, et al., 1989, pp. 7-23; Coffin et al., 1990). Based primarily on their analyses of the existing regional seismic data in conjunction with the drilling information, Munschy et al. (this volume, Chapter 47 ) describe the tectonic evolution of this portion of the plateau.

\section{Site 748}

Site $748\left(58^{\circ} 26.45^{\prime} \mathrm{S}, 78^{\circ} 58.89^{\prime} \mathrm{E}\right.$; water depth, $\left.1290 \mathrm{~m}\right)$ is a (minicone) reentry site located on the Southern Kerguelen Plateau in the western part of the Raggatt Basin, east of Banzare Bank on MCS Line RS02-27 (Figs. 9 and 14). The site was intended to recover an expanded section of Paleogene and Cretaceous sediments that could be used to decipher the tectonic and geologic history of this portion of the plateau.

After coring the upper $215 \mathrm{~m}$ of the section with the APC and $\mathrm{XCB}$ until refusal, the reentry hole was initiated with the $\mathrm{RCB}$ and drilled to $550 \mathrm{mbsf}$, at which point a model Lamar Hayes ( $\mathrm{LH}$ ) reentry minicone was deployed to take advantage of a window of fairly calm weather for that operation. The hole was continued to $742 \mathrm{mbsf}$, whereupon a successful reentry procedure was conducted to change the bit. The hole was then drilled to a total depth of $935 \mathrm{~m}$, at which point a failed flapper value allowed massive backflow of sediments into the bottom hole assembly (BHA), thereby preventing further operations at this site, including logging.

Aside from the sediment recovered from the BHA, little material was trapped in cores (i.e., in core-catcher socks) taken over the basal $27 \mathrm{~m}$ of the hole, perhaps a result of the malfunction of the flapper valve and/or excessive ship heave. Nevertheless, average core recovery over the last $95 \mathrm{~m}$ before these problems happened was $70 \%$, and this is the deepest penetration yet achieved by means of minicone reentry. The following lithologic units were recognized at Site 748: 
Unit I (0-13.3 mbsf): Pleistocene to lower Miocene diatom ooze with radiolarian- and foraminifer-enriched intervals, dropstones, and ice-rafted debris.

Unit II (13.3-389.1 mbsf): upper Miocene to upper Paleocene nannofossil ooze, chalk, porcellanite, and chert, divisible into two subunits.

Subunit IIA (13.3-180.6 mbsf): upper Miocene to middle Eocene nannofossil ooze with a biosiliceous interval.

Subunit IIB (180.6-389.1 mbsf): middle Eocene to upper Paleocene nannofossil ooze, chalk, porcellanite, and chert.

Unit III (389.1-898.8 mbsf): upper Paleocene to upper Cenomanian-Turonian glauconitic packstones, wackestones, siltstones, and claystones, silicified in part and divided as follows into three subunits.

Subunit IIIA (389.1-692.0 mbsf): upper Paleocene to Campanian glauconitic packstones and grainstones, intermittently silicified, with intervals of abundant bryozoans, inoceramid prisms, and crinoid columnals, plus rare red algal debris (thin sections from Samples 120-748C-32R-1, 32-38 cm, and 120748-45R-CC; see "Frontispiece," this volume).

Subunit IIIB (692.0-897.6 mbsf): upper Cenomanian-Coniacian sandstones, siltstones, and claystones (Section 120748C-45R-CC; see "Frontispiece," this volume).

Subunit IIIC (897.6-898.8 mbsf): basalt cobble conglomerate consisting of rounded, altered basalt cobbles and boulders; broken thick-walled mollusk fragments; and a matrix of glauconitic, calcareous siltstones. No baked contact is evident, but sparry calcite veins are common (Intervals 120-748C79R-1, 104-118 and 113-114 cm; see "Frontispiece," this volume).

Unit IV (898.8-935.0 mbsf): highly altered basalt flow and underlying lithologies, divided into two subunits.

Subunit IVA (898.8-902.2 mbsf): sparsely clinopyroxeneplagioclase phyric basalt, strongly weathered and altered.

Subunit IVB (902.2-935.0 mbsf): predominantly downhole cavings from Unit III plus some lithologies not encountered above. All of the material in this subunit was recovered only as drilling chips in core-catcher socks or the BHA; no intact cores were retrieved. Lithologies not observed previously in the hole are (1) red and green claystone and siltstone chips composed of kaolinite, goethite, and traces of hematite (Holmes, this volume, provides detailed descriptions of the clay mineral suites); (2) brown claystones with fine calcite and siderite veins; and (3) highly altered pieces of basalt with alteration-mineral-filled vesicles.

The seismic section (Fig. 14) shows several major reflectors that were located during shipboard studies at $0.92,0.83$, $0.61,0.41,0.29,0.16$, and $0.09 \mathrm{~s}$ TWT below seafloor (Fig. 14) and correlated on the basis of lithology and physical properties with identified lithologic units (Schlich, Wise, et al., 1989, pp. 157-235). These conclusions are confirmed by Fritsch et al. (this volume, Chapter 48) and clearly show up on the synthetic seismogram compiled with corrected core velocities; only minor changes affecting the location of some reflectors were introduced. The proposed correlation between the seismic sequences and the lithologic units clearly associates the K3/P1 boundary with the late Maestrichtian to early Paleocene hiatuses observed at $416 \mathrm{mbsf}$, about $20 \mathrm{~m}$ below the top of lithologic Subunit IIIA (Fritsch et al., this volume, Chapter 48).

The basalt cored at 898.8 mbsf has compositional characteristics similar to intraplate, oceanic-island alkaline basalts. It yielded a radiometric age considerably younger than the basement rocks at other sites dated (Whitechurch, this volume). The unit is believed to represent the last of a series of basalt flows that, for lack of core recovery, can only be inferred to lie within Subunit IVB. The Unit IV basalts are necessarily younger than those that form the true basement of the Raggatt Basin. These younger flows are strongly weathered, and some appear to be interlayered with siltstones and claystones derived from that weathering; wood fragments, apparently in place, denote the development of soils and vegetation on some flows. The kaolinite identified by Holmes (this volume) from the clay- and siltstone drilling chips from the BHA have a mineral composition identical to that of similar age, nonmarine sediment encountered above basement at Site $750 \mathrm{~B}$ (see below). According to regional seismic data, true basement (located at $0.92 \mathrm{~s}$ TWT) was not penetrated at this site, but lay some $90-180 \mathrm{~m}$ below the bottom of Hole 748C (Fig. 14).

Beginning with the basal conglomerate of Subunit IIIC, the first unquestioned marine sediments deposited in this portion of the Raggatt Basin are glauconitic with up to $0.5 \%$ organic matter, denoting a restricted marine environment. No calcareous or siliceous microfossils are preserved, but shore-based palynology studies date them as CenomanianTuronian (Mohr and Gee, this volume, Chapter 19). The high-energy conditions that produced the conglomerate gave way to a more tranquil depositional environment, and silts began to accumulate. Current activity is evident, however, from the occasional cross-laminated sediment and rip-up clasts. Associated with these are a rare megafauna consisting of serpulid worms and delicate, current-oriented bivalves, which Holmes (this volume) suggests may represent storm deposits.

Bitschene et al. (this volume) and Holmes (this volume) describe in detail the glauconitic sequence of Unit III, which is characterized by glauconite contents up to $20 \%$ and appreciable trace amounts of chromium derived from the subaerial weathering and erosion of the surrounding basaltic rocks. As explained by Bitschene et al. (this volume), the chromium enrichment is caused by $\mathrm{Cr}$-spinel and $\mathrm{Cr}$-rich glauconite. The exposed land surrounding the basin supported vegetation, as indicated by the terrestrial wood fragments, pollen, and spores, and it served as a source for fine clastic sediments.

Total organic contents are between $0.2 \%$ and $0.6 \%$ (maximum $1.0 \%$ ). These latter are mostly Type III hydrocarbons composed of terrestrial and highly oxidized marine organic matter.

Datable calcareous microfossils appear at $711 \mathrm{mbsf}$ and are soon followed upcore in Subunit IIIA by a host of invertebrates, the skeletal remains of which, incorporated in the sediment, dramatically increased the proportion of carbonate preserved. Some fossils, such as coralline red algae, serpulid worm tubes, and encrusting bryozoans, indicate periods of quite shallow-water deposition along banks or biothermal reefs (up to inner shelf depths). Most of the skeletal material has been fragmented and redeposited by wave action or currents. Nevertheless, the inoceramid remains, which compose up to $85 \%$ of some intervals, are exceptionally well preserved and might provide reliable isotopic paleotemperature data. Some recovered vertebrate teeth belong to sharks and possibly to the giant swimming lizard Mosasaurus.

Productivity (and consequently sedimentation rates) in this shallow, banklike environment, were quite high, some $60 \mathrm{~m} /$ m.y., and easily kept pace with subsidence. Biogenetic productivity was quite high in the shallow banklike environment represented by the carbonate section (Subunit IIIA), and compensated for the diminishing input of clastic sediments. In addition, siliceous sponges as well as radiolarians, diatoms, and silicoflagellates contributed abundant biogenic silica that was ultimately responsible for the silicified layers in lithologic Subunit IIIA. 
The amount of glauconite produced over the entire $500-\mathrm{m}$ thick Unit III section is extraordinary and is described in detail by Bitschene (this volume) and Holmes (this volume). Because glauconite forms most abundantly in water depths between 50 and $200 \mathrm{~m}$, this site of deposition was maintained close to such depths for an exceedingly long periods of time. Areas like this undoubtedly provided sources of glauconite grains that were swept off such highs and redeposited among sediments in deeper waters (see Rea et al., 1990).

Upper Campanian-Maestrichtian calcareous nannofossil and planktonic foraminifer assemblages have a strong austral affinity, as at Site 747 to the north, and middle Campanian strata are likewise missing (Quilty, this volume, Chapter 22; Watkins, this volume). Middle Campanian strata are also absent in the marginal basins of West Australia (Shaffic, 1990), and this lacuna in the Upper Cretaceous stratigraphy record appears to be a widespread regional phenomena. Watkins (this volume) argues that the high-latitude water mass became decoupled at this time, much as occurred in the South Atlantic sector of the Southern Ocean (Ciesielski et al., 1977). The dinoflagellate assemblages of Subunit IIIB are described by Mao and Mohr (this volume), who also provide a paleobathymetric analysis of the basin based on changes in their assemblages. The co-occurrence of dinoflagellates and nannofossils in the same section here and at Site 750 provides an important opportunity to correlate the zonation schemes of these two phytoplankton groups in this part of the world.

Sedimentation was apparently continuous from the late Campanian into the early Maestrichtian, but a portion of the middle Maestrichtian is missing. The upper Maestrichtian and Danian are also missing (hiatus $=\approx 6-7 \mathrm{~m} . \mathrm{y}$.). This latter gap in the record corresponds to a widespread regional disconformity represented by a prominent reflector on the seismic records (Fig. 14) and is thought to mark a major tectonic and erosional event that affected most of the plateau (i.e., see Schlich, Wise, et al., 1989, summary to "Site 747 " chapter). Coffin et al. (1990) suggest that some of the relief on this surface is actually primary relief that was produced by organic reefs.

Subsidence of Site 748 following the erosional event was quite rapid, possibly as a result of extensional tectonics associated with rifting (e.g., $77^{\circ} \mathrm{E}$ Graben; Munschy et al., this volume, Chapter 47; Fritsch et al., this volume, Chapter 48). Alternatively, there may have been strike-slip motion along the $77^{\circ} \mathrm{E}$ Graben with relatively little extension, as described by Royer and Sandwell (1990) and Coffin and Royer (this volume).

The upper Paleocene through middle Eocene pelagic carbonate and chert sequence is apparently continuous and was deposited in deeper waters (similar to present day) as subsidence had far outstripped the rather high sedimentation rate of $20 \mathrm{~m} / \mathrm{m}$.y. Regional seismic analysis shows that the Paleogene depocenter for the basin had shifted considerably toward the east as a consequence of the profound Maestrichtian tectonic event (Schlich, Wise, et al., 1989, pp. 7-23; Schlich et al., 1989; Coffin et al., 1990; Fritsch et al., this volume, Chapter 6).

Full $(100 \%)$ recovery in the upper $180 \mathrm{~m}$ of the section in Hole $748 \mathrm{~B}$ provides a reasonably good upper Eocene-Neogene calcareous-biosiliceous section with good paleomagnetic control that complements the one obtained from Site 747. This has proven to be the premier high-latitude reference site for integrated biomagnetostratigraphy derived from ODP drilling on the Kerguelen Plateau and Broken Ridge. Extensive biostratigraphic and related investigations have been conducted on this interval (see Abelmann and Lazarus; Ahlbach and McCartney; Aubry; Berggren, Chapters 31 and 35; Firth and
Wise; Harwood and Maruyama; Lazarus; MacKensen; MacKensen and Berggren; MacKensen and Spiegler; McCartney and Harwood; Takemura; Wei and Wise, Chapters 29 and 49; Wei et al., Chapter 55; all this volume with the Neogene portions summarized by Harwood et al., this volume).

The main elements of the magnetic polarity record from Anomaly Correlatives 1-18 (Pleistocene to late Eocene) have been recognized, with updated shore-laboratory analyses provided by Inokuchi and Heider (this volume). Both the upper and lower epoch boundaries of the thick $(65-70 \mathrm{~m})$ Oligocene section are defined by bio- and magnetostratigraphy (Anomaly Correlatives 6C and 13), and age models for this critical interval are proposed by Wei et al. (this volume) and Zachos et al. (this volume), who use primarily nannofossil and planktonic foraminifer datums, respectively.

A striking occurrence of angular quartz sand and micas in the lowermost Oligocene represents ice-rafted debris (IRD). Breza and Wise (this volume) confirmed the presence of this material using the scanning electron microscope (SEM) and microprobe, and they argue that it represents particularly strong evidence for the existence of a substantial ice sheet on the East Antarctica at this time. Zachos et al. (this volume) draw the same conclusion independently from their analysis of the stable isotopes throughout the interval. Wei and Wise (1990) and Wei et al. (this volume) develop a third line of evidence, that of latitudinal gradients defined by nannofossil assemblages, which they believe bolsters the argument. Both Wei and Wise (this volume) and Zachos et al. (this volume) speculate on the size and nature of the earliest Oligocene ice sheet based on their respective analyses. Finally, Wei (this volume, Chapters 63 and 64 ) uses nannofossils to age date ice-rafted sequences reported elsewhere in the southeast Pacific and the Ross Sea (Antarctica) and to argue for the possible existence of not only Oligocene but also Eocene ice sheets on Antarctica. These various studies of the Paleogene glacial history of Antarctica are summarized by Wise et al. (this volume; see also Wise et al., 1991), who speculate that ocean circulation patterns different from those of today allowed large icebergs to reach the Kerguelen Plateau from the Prydz Bay region during the earliest Oligocene.

Two minor hiatuses are present in the Oligocene, and parts of the lower and middle Miocene are missing (hiatus = 5-6 m.y.). A minor late Pliocene hiatus was detected (2.2-3.1 $\mathrm{Ma})$, and the Pleistocene is condensed and discontinuous.

\section{SITE 749}

Site $749\left(58^{\circ} 43.03^{\prime} \mathrm{S}, 76^{\circ} 24.45^{\prime} \mathrm{E}\right.$; water depth, $\left.1069.5 \mathrm{~m}\right)$ is a reentry site located along MCS Line MD47-13 (Figs. 9 and 15) on the western flank of Banzare Bank, on the Southern Kerguelen Plateau. The Banzare Bank corresponds to a smooth basement rise that crests east of the site at a water depth of about $700 \mathrm{~m}$. The sediments gradually thin toward the top of the bank where several faults cut the basement structure. The site was intended to recover extensive basement rocks from the Southern Kerguelen Plateau with the penetration of at least $200 \mathrm{~m}$ of basalt.

A very strong basement reflector is observed at about 0.24 s TWT below seafloor (Fig. 16). Downslope the sediments thicken in all directions, especially by toplap (e.g., Fig. 15). Thus, the oldest sediment cored at this site does not correspond to the age of basement.

The upper $43.8 \mathrm{~m}$ of section was cored with $100 \%$ recovery using the APC until middle Eocene cherts were encountered, which reduced APC and XCB recovery to only $26 \%$ for the subsequent $80 \mathrm{~m}$. A change to the RCB yielded only $7 \%$ recovery through cherts, chalks, and oozes to the basement contact at $202 \mathrm{~m}$. After obtaining $5 \mathrm{~m}$ of basalt, the succeeding 
two cores were essentially empty, and a model LH minicone was deployed that allowed us to reenter the hole after a bit change. This was the first use of a free-fall minicone for a dedicated basement site.

Inspection of the BHA on deck showed that severe pounding of the bit against the hard bottom had occurred in high seas at this shallow site, resulting in a badly worn bit and a broken flapper valve. The latter had precluded any recovery in the last two cores. A novel decision was made by ODP Cruise Operations Superintendent Lamar Hayes to core without a flapper valve and to institute instead a weighted mud program to prevent backflow of cuttings into the BHA. After a successful (16-min) reentry, this procedure worked beyond expectations as the next two cores produced $17.83 \mathrm{~m}$ of basalt at a recovery rate of $94 \%$. As the last core was being cut, a medical emergency involving Mr. Hayes ended operations at this site, and the JOIDES Resolution was put on course for Fremantle, Australia. Mr. Hayes died on 28 March 1988, and the ship arrived at Fremantle on 5 April 1988.

The following lithologic units were recognized at this site:

Unit I (0-0.24 mbsf): Pleistocene to middle Pliocene diatom ooze with foraminifers and ice-rafted debris; disconformity occurs at the base of the unit.

Unit II (0.24-202.0 mbsf): upper Oligocene to lower Eocene nannofossil ooze with chert, chalk, and porcellanite and divisible into two subunits.

Subunit IIA (0.24-43.6 mbsf): upper Oligocene to middle Eocene nannofossil ooze with foraminifers, plus some siliceous microfossils and minor volcanic ash in the upper $25 \mathrm{~m}$.

Subunit IIB (43.6-202.0 mbsf): middle Eocene to lower Eocene nannofossil ooze, with chalk, chert, and porcellanite; $3 \%$ sponge spicules and radiolarians occur only between 53 and 82 mbsf.

Unit III (202.0-249.5 mbsf): clinopyroxene-plagioclase phyric basalts.

The $23.1 \mathrm{~m}$ of recovered basalt consists of 5 flows and 1 dike. Most flows have altered and vesicular tops but grade to fresh and more massive basalt toward the interior of the flow. The basalts are either quartz or olivine normative tholeiites, and range in $\mathrm{Mg}$ from 46.5 to 57.5 . The high $\mathrm{Mg}$ basalt contains olivine and plagioclase $\left(\mathrm{An}_{60-80}\right)$ phenocrysts. All other basalts have plagioclase $\left(\mathrm{An}_{50-60}\right)$ as the main phenocryst phase, together with occasional clinopyroxene. The groundmass phases consist of plagioclase $\left(\mathrm{An}_{40-50}\right)$, clinopyroxene, and $\mathrm{Fe}-\mathrm{Ti}$ oxides.

Shipboard and early shore-based studies revealed that these basalts are more depleted in incompatible trace elements than those from the previous Leg 120 sites, although basalts from Holes $747 \mathrm{C}$ and $749 \mathrm{C}$ have similar $\mathrm{Zr} / \mathrm{Nb}$ and $\mathrm{P} / \mathrm{Y}$ ratios. Both Site 747 and 749 basalts are slightly more enriched in incompatible elements than normal mid-ocean ridge basalt (MORB) and are compositionally similar to transitional basalt (T-MORB). On the basis of major trace element chemistry, Site 749 basalts are similar to the Nauru Basin plateau basalts (Deep Sea Drilling Project [DSDP] Leg 89). In contrast to basalts from Site 747, the basalts from Site 749 do not form a coherent group or trend on key variation diagrams. This indicates that the basalts from Site 749 cannot be related to each other by simple fractional crystallization or partial melting alone.

Basalt alteration occurs in the groundmass, amygdules, and veins as replacement of plagioclase phenocrysts. The alteration assemblage consists of laumontite (and stilbite), interlayered smectite, calcite, and occasional quartz, which is diagnostic of the high-temperature zeolite facies $\left(100^{\circ}-200^{\circ} \mathrm{C}\right)$.
This alteration assemblage at Site 749 was not observed at normal mid-ocean ridge segments, but it did occur in places associated with a high heat flow such as Iceland. The shallow depth of this alteration zone combined with its relative high temperature indicates a high paleoheat flow. Sevigny et al. (this volume) discuss the alteration minerals and their environments in more detail.

The oldest sediments above basement are dated at 54-55 $\mathrm{Ma}$. Benthic foraminifers indicate that the water depth at this site has been virtually constant (between 1000 and $1500 \mathrm{~m}$ ) since the early Eocene. Sedimentation rates, however, vary considerably; we infer rates to be as high as $70 \mathrm{~m} / \mathrm{m}$.y. for the lower and lower middle Eocene, then to drop to $7 \mathrm{~m} / \mathrm{m}$.y. for the upper middle Eocene and $3.6 \mathrm{~m} / \mathrm{m}$.y. for the upper Eocene and Oligocene. The abnormally high sedimentation rate during the early and early middle Eocene may be attributed to constant synsedimentary scouring and redeposition of pelagic oozes, particularly from exposed basement surfaces, thereby contributing to a type of sediment "drift" deposit at this site.

Although only $44 \mathrm{~m}$ of APC cores were obtained at this site, valuable Eocene-Oligocene cores were recovered (Aubry, this volume). Combined with other sections from Site 747 , these provide the basis of a new high-latitude planktonic foraminifer zonation based solely on microperforate tenuitellid forms ( $\mathrm{Li}$ and Banner, this volume).

\section{SITE 750}

Site $750\left(57^{\circ} 35.54^{\prime} \mathrm{S}, 81^{\circ} 14.42^{\prime} \mathrm{E}\right.$; water depth, $\left.2030.5 \mathrm{~m}\right)$ is located on the Southern Kerguelen Plateau in the eastern part of the Raggatt Basin (Fig. 9). Sited west of the deep Labuan Basin on MCS Line RS02-24 (Fig. 16), the site lies approximately $900 \mathrm{~km}$ south of the present-day Polar Front. The primary objective was to recover an expanded Cretaceous section reflecting the early tectonic and depositional history of the Southern Kerguelen Plateau. A second objective was to obtain, if feasible, basement samples from a zone of dipping reflectors in the Raggatt Basin.

Beginning with this site on 14 April 1988, JOIDES Resolution resumed operations on the Southern Kerguelen Plateau following an unscheduled port call to Fremantle, Australia, requiring a transit of 17 days and $4400 \mathrm{nmi}$. Hole $750 \mathrm{~A}$ was wash- and interval-cored with a rotary bit through middle and lower Eocene oozes, chalks, and cherts to $297.5 \mathrm{mbsf}$; below 143 mbsf the combination of cherts and heavy seas had their usual deleterious effect on core recovery, which was only $3 \%$ for the three rotary cores taken. After a 24-hr weather delay, continuous coring through Paleocene-Maestrichtian chalks to 423.3 mbsf yielded a nearly complete but drilling-disturbed $\mathrm{K} / \mathrm{T}$ boundary sequence at $348 \mathrm{mbsf}$; recovery was $47 \%$.

The hole was ended at $460.5 \mathrm{mbsf}$ by total bit failure (disintegration) after only $5 \quad 1 / 2 \quad \mathrm{hr}$ of rotation, whereupon a successful logging run was made using a combination of seismic stratigraphy tools; a second run in rough seas using lithodensity tools was foiled by damage to the cable head. Operations were suspended on 18 April with hopes of reoccupying the site following drilling at Site 751 , located $46 \mathrm{nmi}$ to the west.

As it developed, the site was reoccupied on 20 April 1988, and Hole $750 \mathrm{~B}$ was washed to $450 \mathrm{~m}$ with the RCB, taking only one wash core on the way. After pulling a second wash barrel, the hole was continued with rotary or wash cores taken every $10-30 \mathrm{~m}$ through a section of cherty Cretaceous chalks and limestones. Our intention was to maintain a rate of progress of at least $10 \mathrm{~m} / \mathrm{hr}$. This rate was deemed necessary to reach basement before drilling time for the leg expired if the single bit were to survive to the projected total depth. Drilling with a hard formation bit slowed considerably when the 
formation changed from marine limestone to terrestrial clay below 624 mbsf; however, a velocity inversion at that point considerably decreased the predicted depth to basement, which was encountered at 675.5 mbsf. Thereafter, a series of thick basalt flows were drilled with $67 \%$ recovery to a total depth of 709.7 mbsf.

The following lithologic units, several of which are illustrated in color in the "Frontispiece" (this volume), were recognized:

Unit I (0-0.37 mbsf): lower Pleistocene to middle Pliocene diatom ooze and lag deposit. Repeated within the first core by a double punch of the drill string, this unit contains diatoms and foraminifers of early Pleistocene and middle Pliocene age with a disconformity in between. The lag contains sands and ice-rafted pebbles with heavy manganese coatings; a disconformity occurs at the base.

Unit II (0.37-357.0 mbsf): middle Eocene to lower Paleocene nannofossil ooze, chalk, and chert, divisible into two subunits.

Subunit IIA (0.37-317.2 mbsf): middle Eocene to upper Paleocene white nannofossil ooze, chalk, and chert.

Subunit IIB (317.2-357.0 mbsf): lower Paleocene white nannofossil chalk. Cross-cutting gray dissolution seams are evident below 317 mbsf. Just above the Cretaceous/Tertiary contact, the white chalk darkens downward to an olive gray color; dark specks are present and there is a concomitant increase in magnetic susceptibility. The lowermost Danian nannofossil Zone NP1 is present, but it contains reworked Cretaceous material. The Cretaceous/Tertiary contact (Interval 120-750A-15R-3, 78-94 cm; see "Frontispiece," this volume), which was disturbed by drilling, marks an abrupt change in lithology from well-consolidated Danian chalk to soft Maestrichtian ooze of the nannofossil Nephrolithus frequens Zone. The more clay-rich lower Danian section appears to show up as a positive excursion on the resistivity logs, which may allow a more precise placement of the base of this subunit.

Unit III (357.0-623.5 mbsf): upper Maestrichtian to Cenomanian(?) nannofossil chalk, chert, and intermittently silicified limestone, divided into three subunits.

Subunit IIIA (357.0-450.0 mbsf): upper Maestrichtian to lower Maestrichtian nannofossil chalk and minor chert. Dissolution seams characterize this subunit along with burrows, laminae, and rare stylolites. Some pale purple laminae represent redox changes; three gray laminae contained $50 \%$ zeolite. Microfossils are exceptionally well preserved in the upper Maestrichtian; echinoid spines are a persistent component, and a brachiopod shell was found at $385 \mathrm{mbsf}$.

Subunit IIIB (450.0-594.6 mbsf): lower Maestrichtian to lower Santonian silicified limestone and calcareous chalk, poorly recovered (e.g., Interval 120-750B-9W-1, 134-148 cm; see "Frontispiece," this volume). Bioclast fragments include small mollusks, crinoid columnals, and inoceramids.

Subunit IIIC (594.6-623.5 mbsf): lower Santonian to upper Turonian chalk with dark clayey interlayers (Interval 120750B-11W-1, 75-87 cm; see "Frontispiece," this volume). Cenomanian microfossils may be reworked; the darker clays may be redeposited. Pyritized wood fragments, a bivalve, and traces of glauconite are also present.

Unit IV (623.5-675.5 mbsf): lower Albian, dark gray brown, silty claystone with charcoal and minor conglomerate (e.g., Interval 120-750B-13W-1, 55-70 cm; see "Frontispiece," this volume). Unit IV consists of a broad range of waterlain terrigenous claystones and siltstones, with some sandy or conglomeratic intervals. Carbonized wood fragments from land plants are abundant as are coarse, authigenic siderite and pyrite grains and concretions. Material in the first core recovered from this unit includes massive, plastic reddish brown, silty claystone composed primarily of kaolinite, but with up to $25 \%$ siderite (as coarse authigenic grains), $20 \%$ opaques, $6 \%$ pyrite, and $20 \%$ altered grains that may be derived from basalt. The next core yielded a much darker, nonmarine, grayish brown clayey siltstone that is more fissile and richer in organic matter (up to 7\%). A highly colorful, $25-\mathrm{cm}$-thick interval, soft pebble conglomerate and sand displays grading, cross-stratification, and small-scale current bedding. Incorporated among the rounded to subrounded, 0.5-3-mm diameter, siltstone and claystone ferruginous grains are numerous large (centimeter-scale) pieces of carbonized wood. Wood fragments are also enclosed within sideritecemented claystones, and a siderite concretion occurs at the base of the unit. These nonmarine sediments contain pollen and spores that yield an early Albian age (Mohr and Gee, this volume).

Unit V (675.5-709.7 mbsf): basalt flows composed of moderately to highly altered plagioclase-clinopyroxene phyric basalt. At least four flows were recovered from Unit V; the third flow is an 11.5-m-thick massive basalt flow that represents most of the recovery. The lower two flows are separated by a chilled margin and are overlain by highly altered volcanic rocks. The flows are restricted in composition to olivinehypersthene normative tholeiites. The secondary mineral assemblage consists of interlayered smectite, heulandite-clinoptilolite, calcite, and minor quartz veining.

The basement reflector at Site 750 was located on board on the seismic section (Fig. 16) at $0.69 \mathrm{~s}$ TWT, and three major reflectors were identified at $0.59,0.46$, and $0.31 \mathrm{~s}$ TWT (Schlich, Wise, et al., 1989, pp. 277-337). The seismic sequences were correlated with the different lithologic units essentially on the basis of changes in lithology, physical properties, and logging data. Compared with the results obtained at Site 748 in the western Raggatt Basin, these correlations showed important age discrepancies. Fritsch et al. (this volume, Chapter 48) computed a synthetic seismogram based on corrected Schlumberger velocity logs (Fritsch et al., this volume, Chapter 49) and, for the unlogged intervals, on corrected core velocities. The synthetic seismogram confirms the unusual velocity inversion observed between $600 \mathrm{mbsf}$ and the top of the basalt unit and permits a redefinition of the correlations of the seismic sequences with the different lithologic units. The real basement is located at $0.62 \mathrm{~s}$ TWT; the reflector at $0.69 \mathrm{~s}$ TWT, identified as the basement during the cruise, is an intra-basement reflector located about $100 \mathrm{~m}$ below the bottom of the hole. The $\mathrm{K} 2 / \mathrm{K} 3$ boundary is at $0.58 \mathrm{~s}$ below seafloor TWT and corresponds to the top of Subunit IIIC; the K3/P1 boundary is at $0.37 \mathrm{~s}$ TWT and corresponds now to the top of lithologic Subunit IIIA; the P1/P2 boundary is at $0.24 \mathrm{~s}$ TWT and does not correspond to the boundary of any lithologic unit but is the top of log Unit 2 (Fritsch et al., this volume, Chapter 48).

The basement and sedimentary rocks drilled at this site provide interesting contrasts with those sampled elsewhere on the Kerguelen Plateau during on Leg 120. In terms of incompatible trace element abundances, basalts from Site 750 are the most depleted, thereby extending the array defined by samples from Sites 747 and 749 . They also show slight differences in incompatible element ratios, possibly indicating differences in source characteristics, a topic explored in detail by Salters et al. (this volume).

Nevertheless, Site 750 basement displays transitional characteristics between normal Indian Ocean MORB and Kerguelen Island and Heard Island OIB lavas. The secondary 
mineral assemblage at this site indicates intermediate- to hightemperature alteration, comparable with the temperature regimes defined at Sites 747 and 749 . The alteration occurred under oxidizing conditions. The alteration histories of all of the Leg 120 basalts were compared and contrasted by Sevigny et al. (this volume), and radiometric dates were reported for each site by Whitechurch et al. (this volume), who conclude that the flood basalt eruptions ceased about $110 \mathrm{Ma}$. In addition, paleolatitudes were determined from paleomagnetic studies of the freshest basalts by Inokuchi and Heider (this volume).

Following the emplacement of the uppermost basalts at this site, a considerable portion of the Southern Kerguelen volcanic edifice was emergent during the early Albian and subject to intense weathering in a warm-temperate or subtropical climate (in marked contrast to the climate in this region today). Rainfall was sufficient to weather volcanic rocks to kaolinitic clays. Holmes (this volume) reports gibbsite in these clay mineral assemblages and draws analogies with kaolinite formation in soils of the Hawaiian islands to argue for warm climate conditions with high orographic rainfall. The actual source rock may not have been entirely the tholeiitic basalts drilled at this site, but rather alkaline basalts located elsewhere in the watershed (perhaps similar in composition to those drilled at Site 748).

The soft pebble conglomerates denote fluvial conditions, and the authigenic siderite crystals are characteristic of coal swamps. The numerous large pieces of charcoal (up to $5 \mathrm{~cm}$ ) and high organic carbon contents of up to $10 \%$ attest to the well-forested, terrestrial setting. Holmes (this volume) demonstrates that these sediments are visually and mineralogically similar to those penetrated but poorly sampled in lithologic Unit IV at Site 748 . Both have high organic contents.

Certainly one of the most intriguing histories to come from the studies of these nonmarine sediments is the colonization and development of a terrestrial vegetative cover on the plateau. This can be traced from the time of emergence of the bare volcanic islands to their demise, as heavily forested platforms that eventually subsided beneath the sea. The evidence is developed from two types of paleobotanical analysis. Mohr and Gee (this volume) present pollen and spore data to document a floral succession from a fern ground cover with a low and incomplete canopy of larger vegetation to a climax forest dominated by podocarps that probably formed a fairly complete canopy. Francis and Coffin (this volume), on the other hand, use SEM techniques to analyze the rather abundant charcoalified podocarp wood. They reveal the role that fire, set either by lightning or volcanic eruption, may have played in the development of the island forests.

Foundering of this portion of the Kerguelen platform occurred by Cenomanian times, which according to Holmes (this volume) witnessed the onset of cooler climates, as indicated by major changes in the clay mineral assemblages. The oldest recovered chalks contain evidence of redeposition of inner shelf faunas into a deeper water environment (Quilty, this volume, Chapter 23). Watkins et al. (this volume) demonstrate that, as at Sites 747 and 748, the middle Campanian is missing, suggesting a plateau-wide disconformity (see Fig. 5). By the late Campanian, the subsidence had carried the site to upper slope depths; sedimentation rates increased considerably and surface temperatures cooled, so that planktonic foraminifer assemblages changed from transitional to austral in character (Quilty, this volume, Chapter 22) and the calcareous nannoplankton assemblage strongly resembles the Falkland Province assemblages (Watkins, this volume). Watkins (this volume) presents evidence to suggest that cooling and possibly decoupling of the high-latitude water mass occurred during the time of the mid-Campanian hiatus in sedimentation noted at all of the Leg 120 sites (Fig. 5), a situation analogous to that in the South Atlantic sector of the Southern Ocean (Ciesielski et al., 1977).

By the end of the Cretaceous, the site had deepened to perhaps bathyal depths (Quilty, this volume, Chapter 23). Conditions at this site during the deposition of these Upper Cretaceous chalks were consistently open marine, in strong contrast to the restricted Turonian-Maestrichtian glauconitic siltstones and shallow-water glauconitic bioclastics that characterized the western Raggatt Basin (Site 748). Nor is there evidence of the Maestrichtian-lower Danian debris flows encountered at Site 747 to the north. The western Raggatt Basin stood structurally higher than the eastern portion of the basin throughout the Late Cretaceous, subsiding rapidly only at the end of the Maestrichtian, and Site 748 remains $740 \mathrm{~m}$ shallower than Site 750 today. These different histories are well reflected in our sedimentologic and seismic stratigraphic records (Munschy et al., Chapter 47; Fritsch et al., this volume, Chapter 48).

Surprisingly high sedimentation rates characterize the Campanian-Maestrichtian as well as the Danian (Fig. 5). The latter, with sedimentation rates of $11 \mathrm{~m} / \mathrm{m} . \mathrm{y}$., spans $40 \mathrm{~m}$ of section at Site 750. Danian benthic foraminifer faunas, reported by Mackensen and Berggren (this volume), are similar to those of the upper Maestrichtian; by then, the paleodepth of the site was approaching that of the present day.

Although a complete Cretaceous/Tertiary section was not captured at this site, Ehrendorfer and Aubry (this volume) report a succession of nannofossil taxa similar to that at other high-latitude sites reported from the Southern Ocean (Pospichal and Wise, 1990; Wei and Pospichal, 1991). Zachos et al. (this volume) summarize the sedimentologic, biostratigraphic, and chemostratigraphic information derived from shore-based studies of this $\mathrm{K} / \mathrm{T}$ sequence.

Sedimentation rates increased considerably to about $30 \mathrm{~m} /$ m.y. during the late early and late middle Eocene (Fig. 5). These exceptionally high sedimentation rates denote high regional pelagic productivity. Except for the thin Pliocene/ Pleistocene veneer and lag deposit, the remainder of the Cenozoic is missing at this site.

In summary, the record at Site 750 considerably broadened our understanding of the tectonic and geologic evolution of the Raggatt Basin and the Southern Kerguelen Plateau. It provided (1) a fifth basement site (along with Leg 120 Sites 747, 748 , and 749 and Leg 119 Site 738 ) to help characterize the basalts that underlie the plateau; (2) a record, albeit incomplete because of interval coring, of what appears to be the earliest sedimentation, including nonmarine and marine, recovered at any sites on the plateau; (3) an open-marine Cretaceous, predominantly slope-depth pelagic sequence in the eastern Raggatt Basin, which stands in stark contrast to the restricted and shallow-water section drilled in the western portion of the basin at Site 748; (4) taken together with the open-marine Site 747 to the north and Site $738(\mathrm{Leg} \mathrm{119)}$ to the south, constraints on the geographic extent and the nature of the sedimentologic process responsible for the development of the glauconitic facies in the west; (5) the most expanded high-latitude bathyal record of sedimentation to date throughout the critical Maestrichtian-Danian interval, a most important reference section for integrated biostratigraphic, biogeographic, and geochemical stratigraphic studies; and (6) an important deep-water control point for deciphering the tectonic and subsidence history of the Kerguelen Plateau, one which further suggests an eastward tilting of the Raggatt Basin and an eastward shift in the depocenter following the plateauwide tectonic event near the end of the Cretaceous. The 
subsidence history of the plateau drill sites is examined in considerable detail by Coffin (this volume), whereas Munschy et al. (this volume, Chapter 51) discuss the rifting of Broken Ridge from the eastern Kerguelen Pleateau and the subsequent spreading history of the Southeast Indian Ridge).

With penetration of basement in Hole $750 \mathrm{~B}$, basalt flows had been sampled at four Leg 120 sites. One of the primary objectives of this leg was to determine the nature and origin of the Kerguelen Plateau basement rocks. This was accomplished by the Leg 120 petrologists, whose specific contributions are cited above. No continental basement rocks were drilled at any site. The basalts drilled at the four Leg 120 sites, however, are placed into a larger context by Storey et al. (this volume), who compare and contrast them with other Lower Cretaceous volcanic rocks from the Indian-Australian/Antarctic continental margins. Storey et al. (this volume) also consider the possibility that the basalts of the southernmost portion of the plateau by were contaminated by continental lithosphere during the earliest phases of emplacement.

\section{SITE 751}

Site $751\left(57^{\circ} 43.56^{\prime} \mathrm{S}, 79^{\circ} 48.89^{\prime} \mathrm{E}\right.$, water depth, $\left.1633.8 \mathrm{~m}\right)$ is located in the central part of the Raggatt Basin on the Southern Kerguelen Plateau. It was intended to recover a high-resolution Neogene and Paleogene stratigraphic section deposited above the calcium carbonate compensation depth and well south of the present-day Polar Front, which lies $900 \mathrm{~km}$ to the north. This site is a key component of a latitudinal paleoceanography transect across the plateau. The Marion Dufresne MCS Line MD47-05 shows a thick sedimentary cover of at least $2500 \mathrm{~m}$ at this locality (Figs. 9 and 17). Because of time constraints imposed by an unexpected midcruise round-trip between the Kerguelen Plateau and Fremantle, Australia, drilling at Site 751 was limited to the Neogene objective, which comprises a seismic sequence of $0.24 \mathrm{~s}$ TWT.

A 166.2-m-thick section of the upper Pleistocene through middle lower Miocene mixed biosiliceous and calcareous ooze was cored by the APC for a recovery rate of $98 \%$. An unusual finding was an exceptionally young (early Pliocene age) porcellanite bed encountered in Core 120-751A-2H (see Section 120-751A-6H-1; see "Frontispiece,"' this volume). Operations in high seas were ended when the APC piston rod failed during pullout, leaving the core barrel and the last core stuck in the hole.

The following lithologic units were recognized at Site 751:

Unit I (0-40.1 mbsf): upper Pleistocene (>.0.2 Ma) to lower Pliocene diatom ooze with minor ice-rafted debris, foraminifers, volcanic ash, and porcellanite. The carbonate content ranges from $0 \%$ to $70 \%$, whereas foraminifers range from $\sim 3 \%-25 \%$ near the top to rare near the bottom of the unit. Ice-rafted debris is scattered in minor abundance throughout the unit, mostly as sand-size specks. The predominantly milky-white porcellanite (see the "Frontispiece," this volume), disturbed by drilling, fills the top $44 \mathrm{~cm}$ of Core $120-751 \mathrm{~A}-3 \mathrm{H}$ and contains some burrowlike casts. Two vitric ash layers are present in the lower Pliocene sediments.

Unit II (40.1-166.2 mbsf): upper Miocene to lower Miocene diatom nannofossil ooze. Although nannofossils predominate, diatoms occur in equal or greater abundance in many intervals. Foraminifers, radiolarians, and silicoflagellates are present in rare or trace amounts. Faint green, centimeter-scale laminae enriched in diatoms occur between 88 and 104 mbsf.

The lower Pliocene through lower Miocene represents an expanded section with sedimentation rates of $15-20 \mathrm{~m} / \mathrm{m}$.y., whereas much lower rates of about $3 \mathrm{~m} / \mathrm{m}$.y. characterize the abbreviated upper Pliocene-Pleistocene section. As many as four hiatuses have been detected. The most extensive of these can be correlated across the Raggatt Basin and spans an interval from about 12.5 to $16 \mathrm{Ma}$ in the middle Miocene. The key to delineating these hiatuses is the diatom stratigraphy, which is developed in considerable detail at this and other Neogene sites by Harwood and Maruyama (this volume). In addition, Rack and Julson (this volume) were able to use changes in physical properties to recognize important hiatuses. Magnetostratigraphic data are of mixed quality, but key polarity reversals are identified in the early Pliocene to late Miocene (Anomaly Correlatives 3, 3A, 4, and 5) and early Miocene (Anomaly Correlatives $5 \mathrm{C}$ through 6), as developed by Heider et al. (this volume).

High biogenic silica contents in Unit I yielded low bulk densities and high porosity values relative to Unit II. Compressional wave velocity measurements indicate that the first reflector at $0.24 \mathrm{~s}$ TWT lies just below the bottom of the hole at about $185 \mathrm{~m}$ and may correspond to the Oligocene/Miocene contact. If so, sedimentation rates would suggest that a disconformity could be expected at this point.

The high carbonate contents (Howard, this volume) and high sedimentation rates for the Miocene at this site, plus the co-occurrence of siliceous and calcareous microfossil groups, are unique for these high southern latitudes and make this an important reference section for stable isotope and biomagnetostratigraphic studies. In addition to the diatom and radiolarian stratigraphies developed by Harwood and Maruyama (this volume) and Lazarus (this volume), some useful calcareous microfossil datum levels were identified, even at these high latitudes, by Berggren (this volume, Chapter 35 ) and Wei and Wise (this volume, Chapters 28 and 29). Although they propose no formal zonation, the latter authors correlate useful Miocene nannofossil datums across the plateau using the results from the Leg 119 and 120 sites.

Detailed isotope studies at Site 751 form the basis of a Neogene paleocirculation study of this portion of the plateau by Mackensen et al. (this volume). Complementary studies of ice-rafted detritus and clays are provided by Breza (this volume, Chapters 14 and 60 ). He found that the bulk of the ice-rafted clastic sediments are found in the lower Pliocene, which he correlated with an early Pliocene warming and deglacial event on Antarctica.

\section{ORGANIZATION OF VOLUME}

The chapters that follow are organized in rough stratigraphic order, beginning with articles on basement rocks of the Kerguelen Plateau followed by studies of the sedimentary cover above. Studies of the sediment cover are grouped according to discipline, but they are arranged roughly in stratigraphic sequence where possible. Stable isotope studies of sediments are placed at the end of Sections 5 and 6, which address the paleontology, biostratigraphy, and paleonenvironments of Mesozoic and Cenozoic rocks, respectively. Geophysical studies, which deal with the basement, sediments, or regional tectonics, are placed toward the end, just before the syntheses. The appendix contains studies that address Leg 120 cruise objectives but are based on piston or drill cores taken by other cruises or expeditions.

\section{REFERENCES}

Aubry, M.-P., Berggren, W. A., Kent, D. V., Flynn, J. J., Klitgord, K. D., Obradovich, J. D., and Prothero, D. R., 1988. Paleogene geochronology: an integrated approach. Paleoceanography, 3:707-742. 
Barron, J., Larsen, B., et al., 1989. Proc. ODP, Init. Repts., 119: College Station, TX (Ocean Drilling Program).

Berggren, W. A., Hamilton, N., Johnson, D. A., Pujol, C., Weis, W., Cepek, P., and Gombos, A. M., Jr., 1983. Magnetobiostratigraphy of Deep Sea Drilling Project leg 72, Sites 515-518, Rio Grande Rise (South Atlantic). In Barker, P. R., Carlson, R. L., Johnson, D. A., et al., Init. Repts. DSDP, 72: Washington (U.S. Govt. Printing Office), 939-948.

Berggren, W. A., Kent, D. V., and Flynn, J. J., 1985a. Jurassic to Paleogene: Part 2. Paleogene geochronology and chronostratigraphy. In Snelling, N. J. (Ed.), The Chronology of the Geological Record. Geol. Soc. London Mem., 10:141-195.

Berggren, W. A., Kent, D. V., Flynn, J. J., and Van Couvering, J. A., 1985b. Cenozoic geochronology. Geol. Soc. Am. Bull., 96:14071418.

Berggren, W. A., Kent, D. V., and Van Couvering, J. A., 1985. The Neogene: Part 2. Neogene geochronology and chronostratigraphy. In Snelling, N. J. (Ed.), The Chronology of the Geological Record. Geol. Soc. London Mem., 10:211-260.

Bradley, L. M., and Frey, H., 1988. Constraints on the crustal nature and tectonic history of the Kerguelen Plateau from comparative magnetic modeling using MAGSAT data. Tectonophysics, 145: 243-251.

Cande, S. C., and Mutter, J. C., 1982. A revised identification of the oldest sea-floor spreading anomalies between Australia and Antarctica. Earth Planet. Sci. Lett., 58:151-160.

Ciesielski, P. F., Sliter, W. V., Wind, F. H., and Wise, S. W., 1977. Paleoenvironmental analysis and correlation of a Cretaceous Islas Orcadas core from the Falkland Plateau, Southwest Atlantic. Mar. Micropaleontol., 2:27-34.

Coffin, M. F., Davies, H. L., and Haxby, W. F., 1986. Structure of the Kerguelen Plateau province from SEASAT altimetry and seismic reflection data. Nature, 324:134-136.

Coffin, M. F., Munschy, M., Colwell, J. B., Schlich, R., Davies, H. L., and Li, Z. G., 1990. Seismic stratigraphy of the Raggatt Basin, Southern Kerguelen Plateau: tectonic and paleoceanographic implications. Geol. Soc. Am. Bull., 102:563-579.

Colwell, J. B., Coffin, M. F., Pigram, C. J., Davies, H. L., Stagg, H.M.J., and Hill, P. J., 1988. Seismic stratigraphy and evolution of the Raggatt Basin, southern Kerguelen Plateau. Mar. Pet. Geol., 5:75-81.

Fisher, R. L., Jantsch, M. Z., and Comer, R. L., 1982. General Bathymetric Chart of the Oceans (GEBCO), Scale 1:10,000,000: Ottawa (Canadian Hydrographic Service), 5.9.

Goslin, J., 1981. Etude géophysique des reliefs asismiques de l'océan Indien occidental et austral [Ph.D. thesis]. Univ. Louis Pasteur, Strasbourg, France.

Hayes, D.E., and Vogel, M., 1981. General Bathymetric Chart of the Oceans (GEBCO), Scale 1:10,000,000: Ottawa (Canadian Hydrographic Service), 5.13.

Houtz, R. E., Hayes, D. E., and Markl, R. G., 1977. Kerguelen Plateau bathymetry, sediment distribution and crustal structure. Mar. Geol., 25:95-130.

Kennett, J. P., 1978. The development of planktonic biogeography in the Southern Ocean during the Cenozoic. Mar. Micropaleontol., $3: 301-345$.

Kent, D. V., and Gradstein, F. M., 1985. A Cretaceous and Jurassic geochronology. Geol. Soc. Am. Bull., 96:1419-1427.

Leclaire, L., Bassias, Y., Denis-Clocchiatti, M., Davies, H. L., Gautier, I., Gensous, B., Giannesini, P.-J., Patriat, P., Ségoufin, J., Tesson, M., and Wannesson, J., 1987a. Lower Cretaceous basalt and sediments from the Kerguelen Plateau. Geo-Mar. Lett., 7:169-176.

Leclaire, L., Denis-Clocchiatti, M., Davies, H. L., Gautier, I., Gensous, B., Giannesini, P.-J., Morand, F., Patriat, P., Ségoufin, J., Tesson, M., and Wannesson, J., 1987b. Nature et âge du plateau de Kerguelen-Heard, secteur sud. Résultats préliminaires de la campagne "N.A.S.K.A.-MD48." C.R. Acad. Sci. Ser. 2, 304:23-28.

Leg 120 Scientific Drilling Party, 1988. ODP at Kerguelen Plateau: Leg 120 explores origins and history. Geotimes, 33:12-16.

Leg 120 Shipboard Scientific Party, 1988. That sinking feeling. Nature, 334:385-386.

Le Pichon, X., and Heirtzler, J. R., 1968. Magnetic anomalies in the Indian Ocean and sea-floor spreading. J. Geophys. Res., 73:2101-2117.
Luyendyk, B. P., and Davies, T. A., 1974. Results of DSDP Leg 26 and the geologic history of the Southern Indian Ocean. In Davies, T. A., Luyendyk, B. P., et al., Init. Repts. DSDP, 26: Washington (U.S. Govt. Printing Office), 909-943.

McKenzie, D. P., and Sclater, J. G., 1971. The evolution of the Indian Ocean since the Late Cretaceous. Geophys. J. R. Astron. Soc., 25:437-528.

Munschy, M., and Schlich, R., 1987. Structure and evolution of the Kerguelen-Heard Plateau (Indian Ocean) deduced from seismic stratigraphy studies. Mar. Geol., 76:131-152.

Mutter, J. C., and Cande, S. C., 1983. The early opening between Broken Ridge and Kerguelen Plateau. Earth Planet. Sci. Lett., 65:369-376.

Mutter, J. C., Hegarty, K. A., Cande, S. C., and Weissel, J. K., 1985. Breakup between Australia and Antarctica: a brief review in the light of new data. Tectonophysics, 114:255-279.

Peirce, J., Weissel, J., et al., 1989. Proc. ODP, Init. Repts., 121: College Station, TX (Ocean Drilling Program).

Pospichal, J. J., and Wise, S. W., Jr., 1990. Calcareous nannofossils across the K/T boundary, ODP Hole $690 \mathrm{C}$, Maud Rise, Weddell Sea. In Barker, P. F., Kennett, J. P., et al., Proc. ODP, Sci. Results, 113: College Station, TX (Ocean Drilling Program), 515-532.

Quilty, P.G., 1973. Cenomanian-Turonian and Neogene sediments from northeast of Kerguelen Ridge, Indian Ocean. J. Geol. Soc. Aust., 20:361-371.

Ramsay, D. C., Colwell, J. B., Coffin, M. F., Davies, H. L., Hill, P. J., Pigram, C. J., and Stagg, H.M.J., 1986. New findings from the Kerguelen Plateau. Geology, 14:589-593.

Rea, D. K., Dehn, J., Driscoll, N. W., Farrell, J. W., Janecek, T. R., Owen, R. M., Pospichal, J. J., Resiwati, P., and ODP Leg 121 Scientific Party, 1990. Paleoceanography of the eastern Indian Ocean from ODP Leg 121 drilling on Broken Ridge. Geol. Soc. Am. Bull., 102:679-690.

Recq, M., and Charvis, P., 1986. A seismic refraction survey in the Kerguelen isles, Southern Indian Ocean. Geophys. J. R. Astron. Soc., 84:529-559.

1987. La ride asismique de Kerguelen-Heard. Anomalie du géoide et compensation isostatique. Mar. Geol., 76:301-311.

Recq, M., Charvis, P., and Hirn, A., 1983. Preliminary results on the deep structure of the Kerguelen Ridge, from seismic refraction experiments. C. $R$. Acad. Sci. Ser. 2, 297:903-908.

Rotstein, Y., Schaming, M., Schlich, M., and Colwell, J., 1990. Basin evolution in oceanic volcanic plateaus: seismic reflection evidence from the Kerguelen Plateau, South Indian Ocean. Mar. Pet. Geol., $7: 1-12$.

Royer, J.-Y., and Sandwell, D. T., 1990. Evolution of the eastern Indian Ocean since the Late Cretaceous: constraints from GEOSAT altimetry. J. Geophys. Res., 94:13755-13782.

Schaming, M., and Rotstein, Y., 1990. Basement reflectors in the Kerguelen Plateau, South Indian Ocean: indications for the structure and early history of the plateau. Geol. Soc. Am. Bull., 102:580-592.

Schlich, R., 1975. Structure et âge de l'océan Indien occidental. Mem. Hors-Ser. Soc. Geol. Fr., 6:1-103.

1982. The Indian Ocean: aseismic ridges, spreading centers, and oceanic basins. In Nairn, A.E.M., and Stehli, F. G. (Eds.), The Ocean Basins and Margins (Vol. 6): New York (Plenum), 51-147.

Schlich, R., Coffin, M. F., Munschy, M., Stagg, H.M.J., Li, Z. G., and Revill, K., 1987. Bathymetric Chart of the Kerguelen Plateau. Jointly edited by Bureau of Mineral Resources, Geology and Geophysics, Canberra, Australia, Institut de Physique du Globe, Strasbourg, France, and Territoire des Terres Australes et Antarctiques Franêaises, Paris, France.

Schlich, R., Delteil, J., Moulin, J., Patriat, P., and Guillaume, R., 1971. Mise en évidence d'une sédimentation de marge continentale sur le plateau de Kerguelen-Heard. C. R. Acad. Sci. Ser. 2, 272:2060-2063.

Schlich, R., Munschy, M., Boulanger, D., Cantin, B., Coffin, M. F., Durand, J., Humler, E., Li, Z. G., Savary, J., Schaming, M., and Tissot, J. D., 1988. Résultats préliminaires de la campagne océanographique de sismique reflexion multitraces MD47 dans le domaine sud du plateau de Kerguelen. C. R. Acad. Sci. Ser. 2., 305:635-642. 
Schlich, R., and ODP Leg 120 Scientific Party, 1989. Résultats préliminaires de la campagne de forages du Joides Résolution sur le plateau de Kerguelen (ODP leg 120). C. R. Acad. Sci. Ser. 2, 308:1597-1603.

Schlich, R., and Patriat, P., 1967. Profils magnétiques sur la dorsale médio-océanique "Indo-Pacifique." Ann. Geophys. C.N.R.S., 23:629-633.

1971b. Mise en évidence d'anomalies magnétiques axiales sur la branche ouest de la dorsale médio-indienne. C. R. Acad. Sci. Ser. 2, 272:700-703.

1971a. Anomalies magnétiques de la branche et de la dorsale médio-indienne entre les îles Amsterdam et Kerguelen. $C$. R. Acad. Sci., Ser. 2, 272:773-776.

Schlich, R., Wise, S. W., Jr., et al., 1989. Proc. ODP, Init. Repts., 120: College Station, TX (Ocean Drilling Program).

Shafik, S., 1990. Late Cretaceous nannofossil biostratigraphy and biogeography of the Australian western margin. Bull.-Bur. Min. Resour. Geol. Geophys. Aust., 295:1-164.

Wei, W., and Pospichal, J. J., 1991. Danian calcareous nannofossil succession at ODP Site 738 in the southern Indian Ocean. In Barron, J., Larsen, B., et al., Proc. ODP, Sci. Results, 119: College Station, TX (Ocean Drilling Program), 493-510.
Wei, W., and Wise, S. W., Jr., 1990. Biogeographic gradients of middle Eocene-Oligocene calcareous nannoplankton in the South Atlantic Ocean. Palaeogeogr., Palaeoclimatol., Palaeoecol., 79: 29-61.

Weissel, J., Peirce, J., Taylor, E., and Alt, J., et al., 1991. Proc. ODP, Sci. Results, 121: College Station, TX (Ocean Drilling Program).

Wicquart, E., 1983. Modèle lithostratigraphique du plateau de Kerguelen-Heard, océan Indien [Thèse de troisième cycle]. Univ. P. et M. Curie, Paris, France.

Wicquart, E., and Fröhlich, F., 1986. La sédimentation sur le plateau de Kerguelen-Heard: relations avec l'évolution de l'océan Indien au Cenozoique. Bull. Soc. Geol. Fr., 8:569-574.

Wise, S. W., Jr., Breza, J. R., Harwood, D. M., Wei, W., 1991. Paleogene glacial history of Antarctica. In Müller, D. W., McKenzie, J. A., and Weissert, H., (Eds.), Controversies in Modern Geology: London (Academic Press), 133-171.

Date of initial receipt: 1 October 1990

Date of acceptance: 8 May 1991

Ms 120B-203 